\title{
16. QUANTITATIVE DISTRIBUTION PATTERNS OF OLIGOCENE AND MIOCENE CALCAREOUS NANNOFOSSILS FROM THE WESTERN EQUATORIAL INDIAN OCEAN1
}

\author{
Eliana Fornaciari, ${ }^{2}$ Isabella Raffi, ${ }^{3}$ Domenico Rio, ${ }^{2}$ Guiliana Villa, ${ }^{3}$ Jan Backman, ${ }^{4}$ and Gunnar Olafsson ${ }^{4}$
}

\begin{abstract}
Biostratigraphically useful nannofossil markers were investigated by means of quantitative methods in Oligocene through middle Miocene sediments from the western tropical Indian Ocean. In the Oligocene a distinct shift in dominance between Sphenolithus predistentus and Sphenolithus distentus represents a better marker event than the first occurrence (FO) of the latter for recognition of the CP17/CP18 boundary. Similarly, the shift in dominance between $S$. distentus and Sphenolithus ciperoensis at 28.8 Ma provides a more reliable indication for the CP19a/CP19b (NP24/ NP25) boundary than the last occurrence (LO) of the former species, which may occur as late as $27.4 \mathrm{Ma}$. Because it is rare in the critical interval and occurs well within the early Miocene, the LO of Helicosphaera recta (NP25/NN1 boundary) provides unreliable biostratigraphic information

In the Miocene, an acme interval of Sphenolithus delphix that ranges in age from 23.6 to $24.7 \mathrm{Ma}$, is an important addition to the poorly resolved biostratigraphy of the early Miocene. The midpoint of this short acme interval of $S$. delphix would form a suitable criterion for replacing the formal CN1a/CN1b boundary definition (end acme Cyclicargolithus abisectus), which has never been defined quantitatively.

No overlap in the ranges of Sphenolithus belemnos and Sphenolithus heteromorphus was observed. The LO of Coronocyclus nitescens provides a more reliable biostratigraphic signal than the FO of Discoaster kugleri for subdivision of the CN5 (NN6-NN7) interval. Biometric analysis of Calcidiscus placolith size revealed a clear bimodal distribution into forms larger or smaller than $10 \mu \mathrm{m}$, in sediments of late Pliocene-early Pleistocene age. The middle Miocene populations, however, are clearly unimodal. Morphotypes $>11 \mu \mathrm{m}$ appear rather distinctly in Subzone CN5b between about 11 and $12 \mathrm{Ma}$.
\end{abstract}

\section{INTRODUCTION}

Recent work by Backman and Shackleton (1983) and Rio et al. (1989) indicates that a quantitative approach provides many benefits to calcareous nannofossil biostratigraphy. Quantitative methods allow, for example, the evaluation of biostratigraphic noise because of reworking, sediment mixing, or operational procedures. Quantitative analysis in closely spaced samples combined with magnetostratigraphy provides clues to the reliability and synchroneity of appearance and extinction datums of index species and, thus, also provides estimates of the precision attainable in biostratigraphic correlation. Furthermore, quantitative methods also yield information on important abundance patterns, such as acme intervals.

Quantitative biostratigraphic approaches have been widely used in Pliocene and Pleistocene deep-sea sediments and have resulted in a high biostratigraphic resolution. During the past 5 $\mathrm{Ma}$, some 15-17 datums have been established that can be correlated with a high degree of precision over wide geographic areas (Rio et al., 1989). In contrast, quantitative studies have been few of calcareous nannofossils from Oligocene and Miocene sediments (Olafsson, 1989), and the biostratigraphic resolution is low compared with that available in the Pliocene and Pleistocene. The biostratigraphic scheme of Bukry $(1973,1975)$ for the Miocene series, the most detailed available, provides 15 events for a time interval of about 20 m.y. This low resolution partly depends on characters inherent in the biostratigraphic record such as low evolutionary rates, but it also depends on the

\footnotetext{
${ }^{1}$ Duncan, R. A., Backman, J., Peterson, L. C., et al., 1990. Proc. ODP, Sci. Results, 115: College Station, TX (Ocean Drilling Program).

2 Dipartimento di Geologia, Università di Padova, Italia.

3 Istituto di Geologia, Università di Parma, Italia.

4 Department of Geology, University of Stockholm, Sweden.
}

fact that few attempts have been made to test other events than those used in the standard zonations.

Leg 115 provided the first hydraulically piston-cored pelagic sediments from the western equatorial Indian Ocean and recovered extended Oligocene and Miocene sequences. These present a good opportunity to establish quantitative distribution patterns of primary and secondary calcareous nannofossil markers. In this paper, we document these distributions to help us investigate the reliability of marker species and the biostratigraphic usefulness of secondary species as well as improve biostratigraphic resolution and precision in the Oligocene and Miocene calcareous nannofossil biostratigraphy.

\section{MATERIAL STUDIED}

The stratigraphic setting and the calcareous nannofossil biostratigraphy of the sedimentary sequence at each Leg 115 site has been discussed by Okada (this volume) and Rio et al. (this volume). In the present work, we consider Oligocene and Miocene sediments retrieved from Sites 714 and 715 , located on the northern Maldives Ridge, and from Sites 707, 708, 709, 710, and 711 , located in the northern Mascarene Plateau and surrounding areas (Table 1 and Fig.1). Sites 707 through 711 represent a depth transect (carbonate bathymetric transect, CBT) drilled in a narrowly confined area to investigate the history of carbonate flux and dissolution during the Neogene (Backman, Duncan, et al., 1988). The Oligocene and Miocene records at the CBT sites are complicated because of the presence of hiatuses and the influence of redeposition processes (Rio et al., this volume). We will present and discuss the data obtained from intervals in which reworking is minimal to help establish the original distribution patterns of the taxa of interest.

\section{METHODS}

The preparation of smear slides for light microscope examination followed standard techniques. Quantitative data were collected in the light microscope following three methods: (1) count- 
Table 1. Summary of Leg 115 sites and holes studies in this chapter.

\begin{tabular}{lllll}
\hline Hole & Latitude & Longitude & $\begin{array}{c}\text { Water } \\
\text { depth } \\
(\mathrm{m})\end{array}$ & \multicolumn{1}{c}{$\begin{array}{l}\text { Studied } \\
\text { interval }\end{array}$} \\
\hline $707 \mathrm{~A}$ & $7^{\circ} 32.72^{\prime} \mathrm{S}$ & $59^{\circ} 01.01^{\prime} \mathrm{E}$ & 1552.3 & $\mathrm{CP} 19 \mathrm{a}-\mathrm{CN} 1 \mathrm{~b}$ \\
$708 \mathrm{~A}$ & $5^{\circ} 27.35^{\prime} \mathrm{S}$ & $59^{\circ} 56.63^{\prime} \mathrm{E}$ & 4109.3 & $\mathrm{CP} 18-\mathrm{CN} 2$ \\
$709 \mathrm{C}$ & $3^{\circ} 54.9^{\prime} \mathrm{S}$ & $60^{\circ} 33.1^{\prime} \mathrm{E}$ & 3040.8 & $\mathrm{CP} 17-\mathrm{CN} 3$ \\
$710 \mathrm{~A}$ & $4^{\circ} 18.7^{\prime} \mathrm{S}$ & $60^{\circ} 58.8^{\prime} \mathrm{E}$ & 3824.3 & $\mathrm{CP} 17-\mathrm{CN} 6$ \\
$711 \mathrm{~A}$ & $2^{\circ} 44.56^{\prime} \mathrm{S}$ & $61^{\circ} 09.78^{\prime} \mathrm{E}$ & 4429.8 & $\mathrm{CP} 17-\mathrm{CN} 1 \mathrm{c}$ \\
$711 \mathrm{~B}$ & & & & CP19a-CN1c \\
$714 \mathrm{~A}$ & $5^{\circ} 03.8^{\prime} \mathrm{N}$ & $73^{\circ} 47.2^{\prime} \mathrm{E}$ & 2038.3 & $\mathrm{CP} 19 \mathrm{a}-\mathrm{CP} 19 \mathrm{~b}, \mathrm{CN} 1-\mathrm{CN} 5 \mathrm{~b}$ \\
$714 \mathrm{~B}$ & & & & $\mathrm{CN} 5$ \\
$715 \mathrm{~A}$ & $5^{\circ} 04.89^{\prime} \mathrm{N}$ & $73^{\circ} 49.88^{\prime} \mathrm{E}$ & 2266.3 & $\mathrm{CN1}-\mathrm{CN} 4$ \\
\hline
\end{tabular}

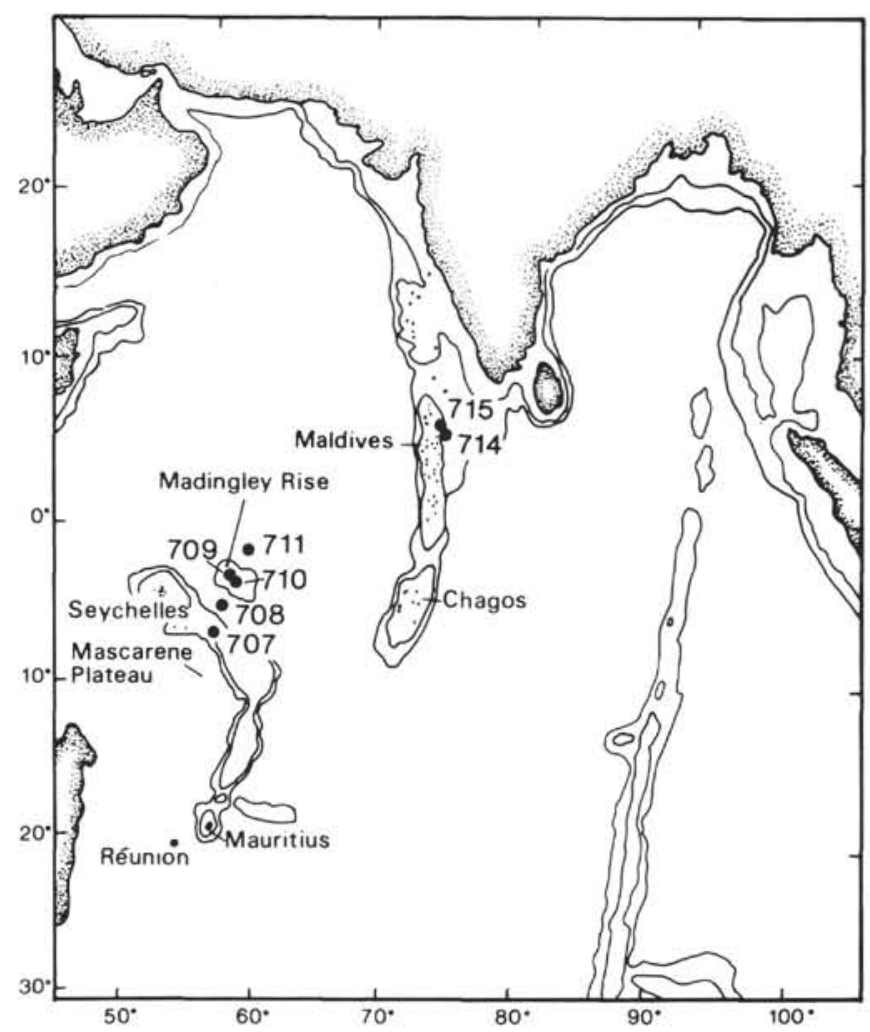

Figure 1. Location map for Leg 115 sites studied in this chapter.

ing the index species vs. the total assemblage; (2) counting the index species vs. a fixed number of taxonomically related forms; and (3) counting the number of specimens of a index species per unit area of the smear slide.

Backman and Shackleton (1983) and Rio et al. (1989) have discussed these three methods at length, indicating their respective advantages and limits of applicability. For comparative purposes, we have in some instances applied two of these counting methods for the same events.

\section{REMARKS ON TAXONOMY}

Taxa investigated in the present work are listed by specific epithet in the Taxonomic List. Bibliographic references for these species are given in Loeblich and Tappan (1966, 1968, 1969, 1970a, 1970b, 1971, 1973) and in Van Heck (1979a, 1979b, $1980 \mathrm{a}, 1980 \mathrm{~b}, 1981 \mathrm{a}, 1981 \mathrm{~b}, 1982 \mathrm{a}, 1982 \mathrm{~b}$ ). Rio et al. (this volume) discuss the taxonomic concepts used for the Miocene taxa. New Miocene sphenoliths, recently described by Rio et al. (in press), are illustrated in Plate 3. Here, we limit our discussion to criteria followed in recognizing the Oligocene taxonomic categories.

Sphenolithus predistentus, Sphenolithus distentus, and Sphenolithus ciperoensis form a well-known lineage that provides the basis for the nannofossil subdivision of the Oligocene series. Recognition of the end members of these three species is easily accomplished through the light microscope, using crossed nicols, by orienting the specimen with its long axis at a $45^{\circ}$ angle to the polarizing direction (Bramlette and Wilcoxon, 1967). There is, however, an almost continuous evolutionary transition from the Eocene $S$. predistentus to the upper Oligocene $S$. ciperoensis. Because these sphenoliths are critical for Oligocene biostratigraphy, it is important to make a clear distinction between the various morphotypes. Huang (1977) attempted such a subdivision. During a preliminary phase of this work, we tried to follow Huang's detailed subdivision. As the resulting biostratigraphic distribution of the different morphotypes did not appear meaningful, we report the data using the following concepts.

Sphenolithus predistentus (Plate 1, Figs. 1-5) includes morphotypes that have a small to very small proximal shield and that show an extinction line between the proximal shield and the apical spine almost parallel to the base when the apical spine is oriented at $45^{\circ}$ to the crossed nicols.

Sphenolithus distentus (Plate 1, Figs. 6-10) includes morphotypes in which the extinction lines between the basal shield and the apical spine join each other, being more or less curved and extending more or less upward.

Sphenolithus ciperoensis (Plate 1, Figs. 11-13) includes morphotypes that show disjunct extinction lines with a continuous bright area between the apical spine and the basal column when oriented with the spine at $45^{\circ}$ to crossed nicols.

We have also counted a sphenolith related to this lineage (Sphenolithus sp. 1) that is morphologically different and has a restricted stratigraphic distribution. This form is robust and possesses a large apical spine. It is distinct from the other members of the lineage in crossed nicols at $45^{\circ}$, showing the curved and bending downward extinction lines between the basal shield and the apical spines (Plate 2, Figs. 8-9).

In the early Oligocene a form of Reticulofenestra, about 10 $\mu \mathrm{m}$ in size, was observed (referred to as Reticulofenestra sp. 1, Plate 2, Figs. 8 and 9) that is similar to Reticulofenestra umbilicus and to Reticulofenestra hillae, from which it is distinguished by its smaller size.

Cyclicargolithus abisectus is a controversial taxonomic category (Olafsson, 1989; Rio et al., this volume). We have separated the distribution of large forms ( $>10 \mu \mathrm{m}$; Plate 2, Fig. 10) from small ones $(<10 \mu \mathrm{m})$. The latter are difficult to distinguish from Cyclicargolithus floridanus.

Medium- to small-sized placoliths with a perforated central area (Plate 2, Fig. 11) were referred to as Clausicoccus fenestratus, following Prins (1979). This species is commonly referred to as Ericsonia fenestrata in the literature.

Easily recognized species include Dictycoccites bisectus (Plate 2, Fig. 5), Zygrhablithus bijugatus (Plate 2, Fig. 12), Helicosphaera compacta (Plate 2, Fig. 7), and Triquetrorhabdulus carinatus.

\section{OLIGOCENE BIOSTRATIGRAPHIC EVENTS}

The biostratigraphic resolution in the late early and late Oligocene is notably low. In the zonations of Martini (1971) and Okada and Bukry (1980), the basis of the subdivision of the time interval from the Reticulofenestra umbilicus LO (about 34 Ma; Backman, 1987) to the Oligocene/Miocene boundary (about $25 \mathrm{Ma}$ ) is provided primarily by the evolution of the $S$. predistentus $-S$. distentus-S. ciperoensis lineage. The following events were used: 
1. the FO of $S$. distentus (base of Subzone CP18);

2. the FO of S. ciperoensis (base of Subzone CP19a and Zone NP24);

3. the LO of S. distentus (base of Subzone CP19b and Zone NP25); and

4. the LO of S. ciperoensis (base of Subzone CN1a).

In addition, Bukry (1973) used the LO of Dictyococcites bisectus as a secondary marker to recognize the base of Subzone CN1a. Martini (1971) originally defined the last Paleogene Zone NP25 by the LO of Helicosphaera recta. Martini and Müller (1986) proposed the FO of Cyclicargolithus abisectus (to approximate the base of Zone NP24), the LO of Zygrhablithus bijugatus (to approximate the top of Zone NP25 in neritic sediments), and the LO of Clausicoccus fenestratus (at the top of Zone NP25) as late Oligocene supplementary events.

In Figures 2-8, we have reported the distribution patterns of the species defining the above events in the investigated sites. We have also reported the distribution patterns of other species, Sphenolithus sp. 1, Helicosphaera compacta, and Reticulofenestra sp. 1, that apparently show a restricted distribution and may prove to be useful from a biostratigraphic point of view.

\section{The $S$. predistentus $-S$. distentus $-S$. ciperoensis Lineage}

The distribution pattern of members of this lineage was determined by counting 100 sphenoliths (Figs. 2-8). Characteristic abundance shifts in dominance occur among the adopted taxonomic categories. Together with the presence of numerous intermediate morphotypes, this supports the idea of phylogenetic and ecologic affinity of the members of this lineage. Such shifts in dominance may, in many cases, provide biostratigraphic signals that are more reliable than the absolute first and last occurrences. This is particularly true for the FO of $S$. distentus because this species is rare and occurs discontinuously in the early part of its range (Fig. 6).

The sharp abundance transition from dominant $S$. predistentus to dominant $S$. distentus (Figs. 4, 5, and 6) clearly represents a better event than the FO of $S$. distentus for subdividing the interval between the LO of $R$. umbilicus and the FO of S. cipero- ensis (Zone NP23 of Martini, 1971). Sphenolithus ciperoensis is also rare during its early range (Figs. 3-6), but it is easily distinguished from other members of the lineage and shows an apparently continuous distribution. The FO of $S$. ciperoensis, although associated with low abundance, is considered to be a useful event, therefore.

The extinction of $S$. distentus is again difficult to pinpoint accurately (Figs. 3 and 5-7). This may be caused partly by reworking problems in our material. Regardless of this particular problem, we consider that the distinct drop in abundance of $S$. distentus, occurring concomitantly with a sharp increase of $S$. ciperoensis and the virtual disappearance of $S$. predistentus (Figs. 3-6), represents a better biostratigraphic signal than the absolute LO of $S$. distentus for recognition of the NP24/NP25 (CP19a/CP19b) boundary.

The end of the continuous presence of $S$. ciperoensis is easily recognized in the investigated sequences (Figs. 2-6). Sporadic occurrences above the last continuous distribution (Figs. 3 and 7) are better explained by reworking rather than by the reappearance of the species (Bizon and Müller, 1979), as they occur at levels in which obviously reworked forms are present. Sphenolithus sp. 1 occurs in low abundance and in a restricted interval below the FO of $S$. ciperoensis at Holes 709C, 710A, and 711A (Figs. 4-6).

\section{Cyclicargolithus abisectus}

Only large forms of $C$. abisectus $(>10 \mu \mathrm{m})$ are considered to be useful biostratigraphically in the Oligocene. Percentages of this form were produced at all sites by counting 500 nannofossil specimens (Figs. 2-3 and 5-6). At Holes 709C and 714A and at Site 711 (Figs. 4 and 6-8), the abundance pattern of C. abisectus was determined with the additional help of the areal counting method. The two methods provide comparable results, although areal counts inherently provide a much larger background of nannofossil specimens. Typical specimens of $C$. abisectus are present below the FO of $S$. ciperoensis, that is, in Zone NP23. It is only in the lower part of NP24 (CP19a), however, that $C$. abisectus becomes firmly established, although never in high abundances (see Fig. 6). The large C. abisectus

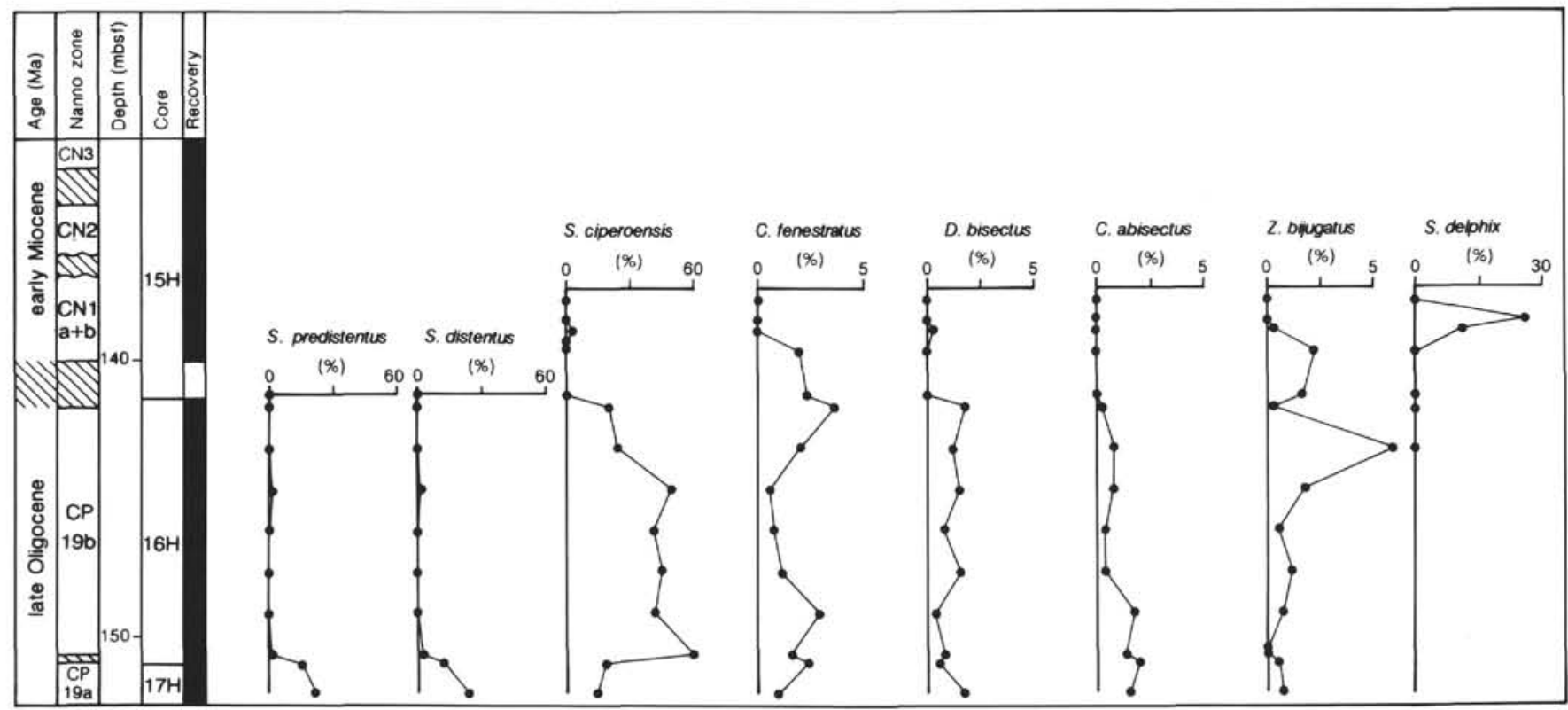

Figure 2. Abundance patterns of Oligocene and early Miocene sphenoliths and other selected calcareous nannofossils at Hole 707A. Percentages of Sphenolithus forms were determined from counts of 100 sphenoliths. Other index form percentages are vs. the total nannofossil assemblage. 


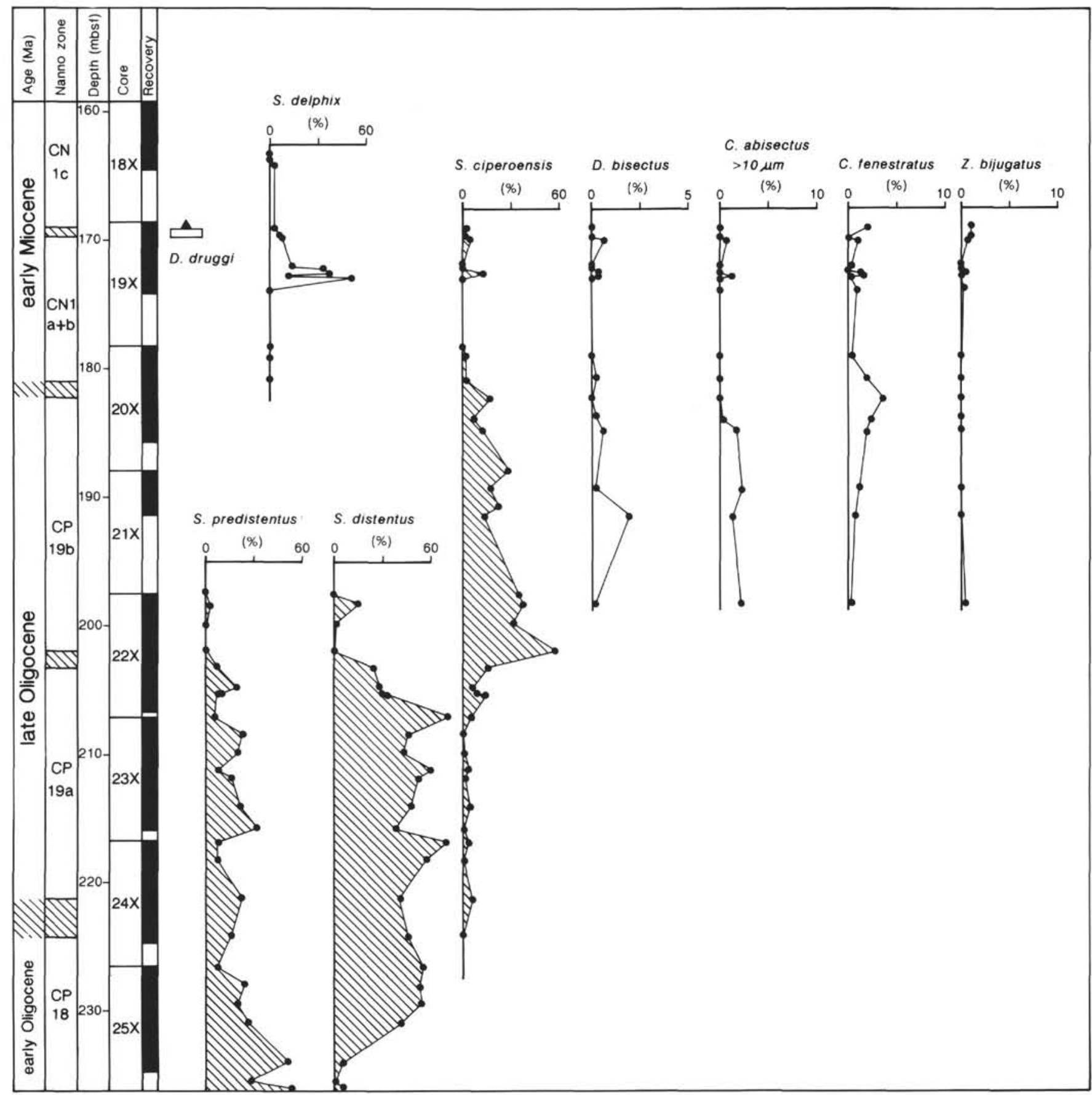

Figure 3. Abundance patterns of Oligocene and early Miocene sphenoliths and other selected calcareous nannofossils at Hole 708A. See Figure 2 for counting methods.

disappears in the equatorial Indian Ocean together with $S$. ciperoensis, being rare during its final range (Figs. 2-6).

The end of the acme of $C$. abisectus close to the Oligocene/ Miocene boundary was originally described by Bukry (1971) from the Pacific Ocean and subsequently used as boundary definition (CN1a/CN1b boundary) in his low-latitude zonation (Bukry, 1973; Okada and Bukry, 1980). This zonal boundary criterion was never defined quantitatively. Our quantitatively derived results from the equatorial Indian Ocean do not reveal any character in the abundance pattern of $C$. abisectus (which may be referred to as an acme interval), which probably suggests that Bukry's original observation only has local value.

\section{Reticulofenestra sp. 1}

The percentages of this medium-sized reticulofenestrid were calculated from counts of 500 nannofossil specimens (Figs. 46). This form is restricted to Zone NP23, is abundant in some samples, and hence may be useful to monitor this zonal interval.

\section{Helicosphaera compacta}

This large helicolith is present in low abundances in the early Oligocene sediments retrieved at Holes 709C, 710A, and 711A (Figs. 5 and 6). Perch-Nielsen (1985) reported $H$. compacta as becoming extinct during Zone NP24 (CP19a). In the material 


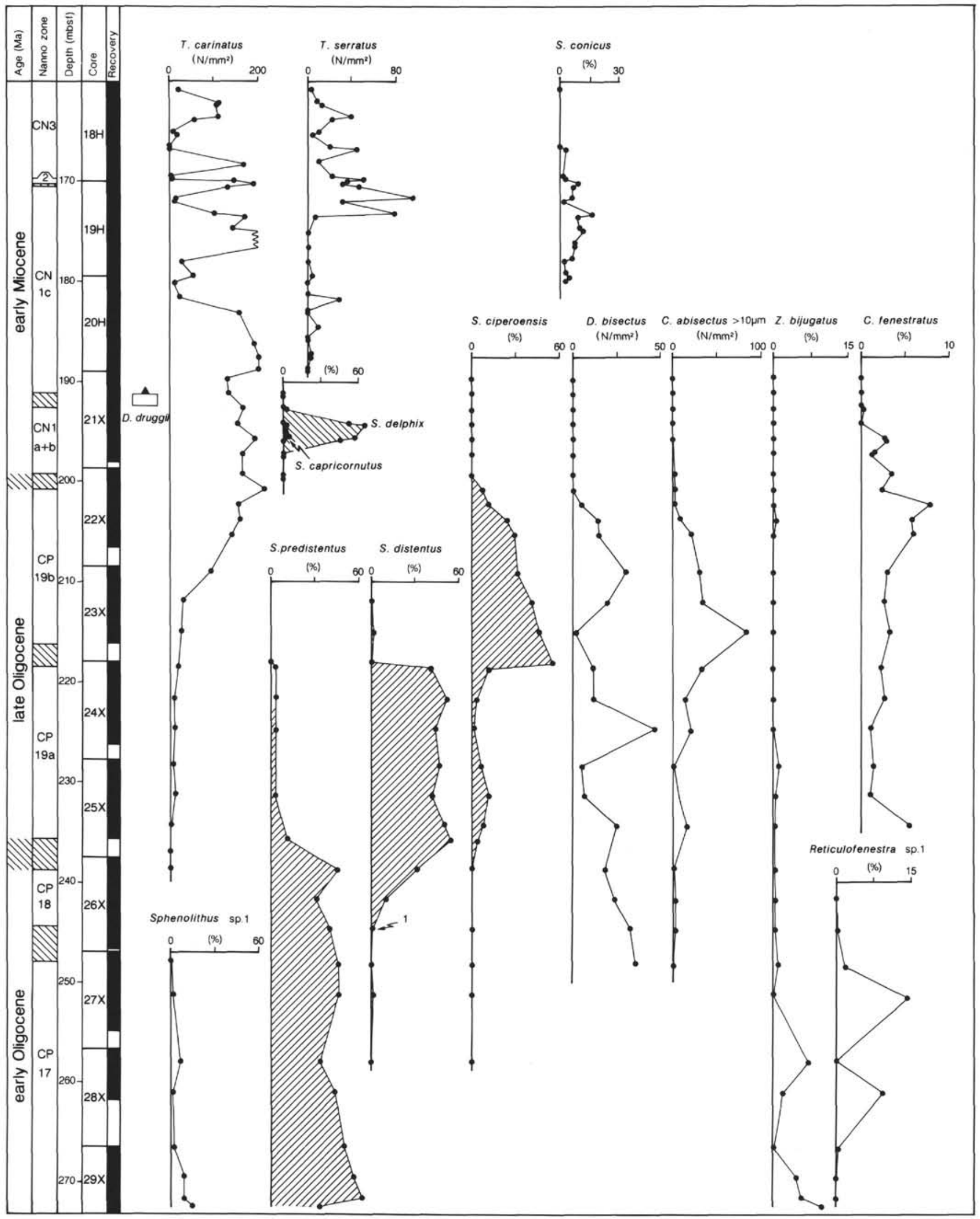

Figure 4. Abundance patterns of Oligocene and early Miocene sphenoliths and other selected calcareous nannofossils at Hole $709 \mathrm{C} . \mathrm{N} / \mathrm{mm}^{2}=\mathrm{num}-$ ber of specimens per square millimeter. See Figure 2 for counting methods. 


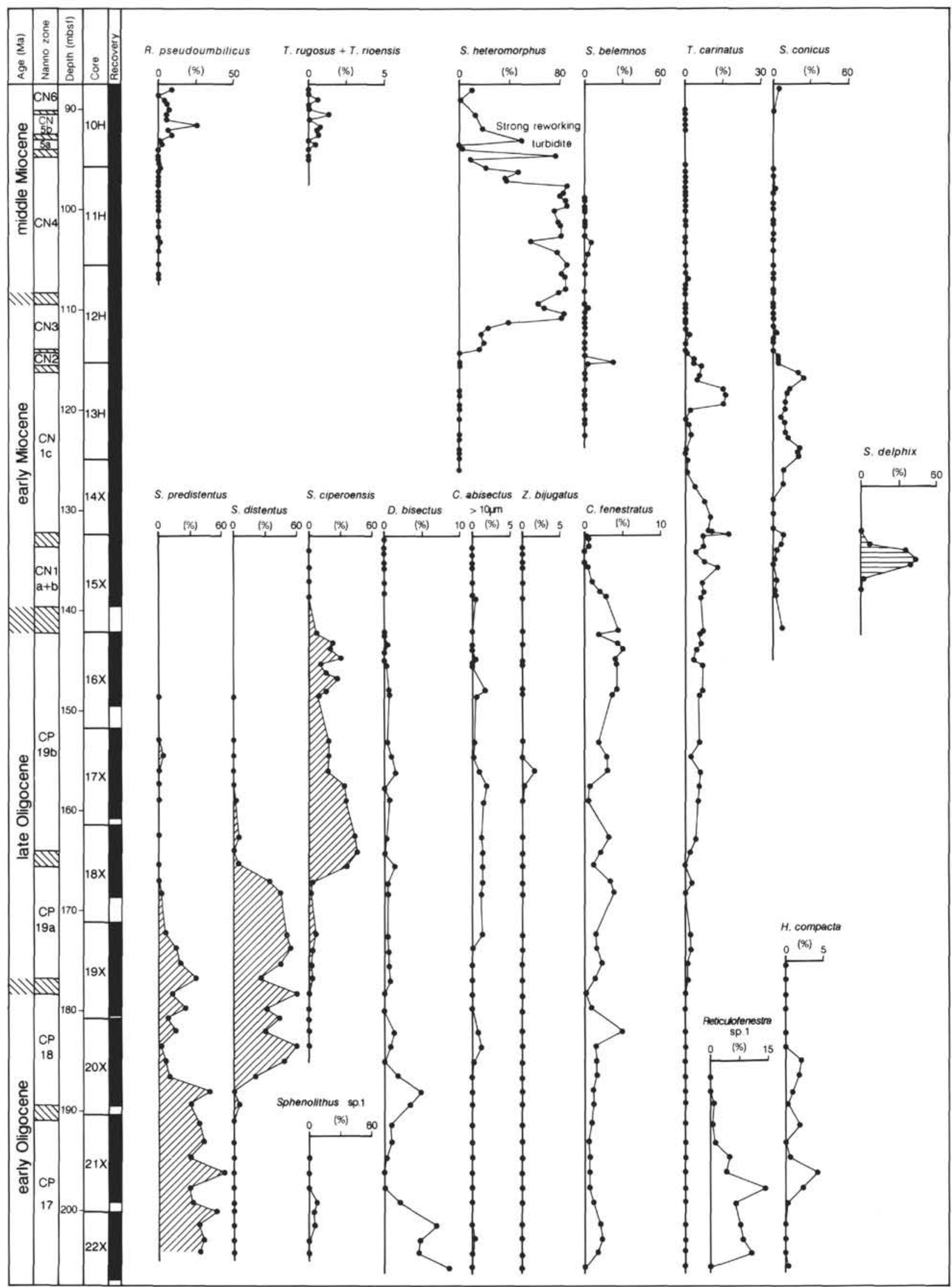

Figure 5. Abundance patterns of Oligocene and early Miocene sphenoliths and selected index calcareous nannofossils at Hole 710A. See Figure 2 for counting methods. 


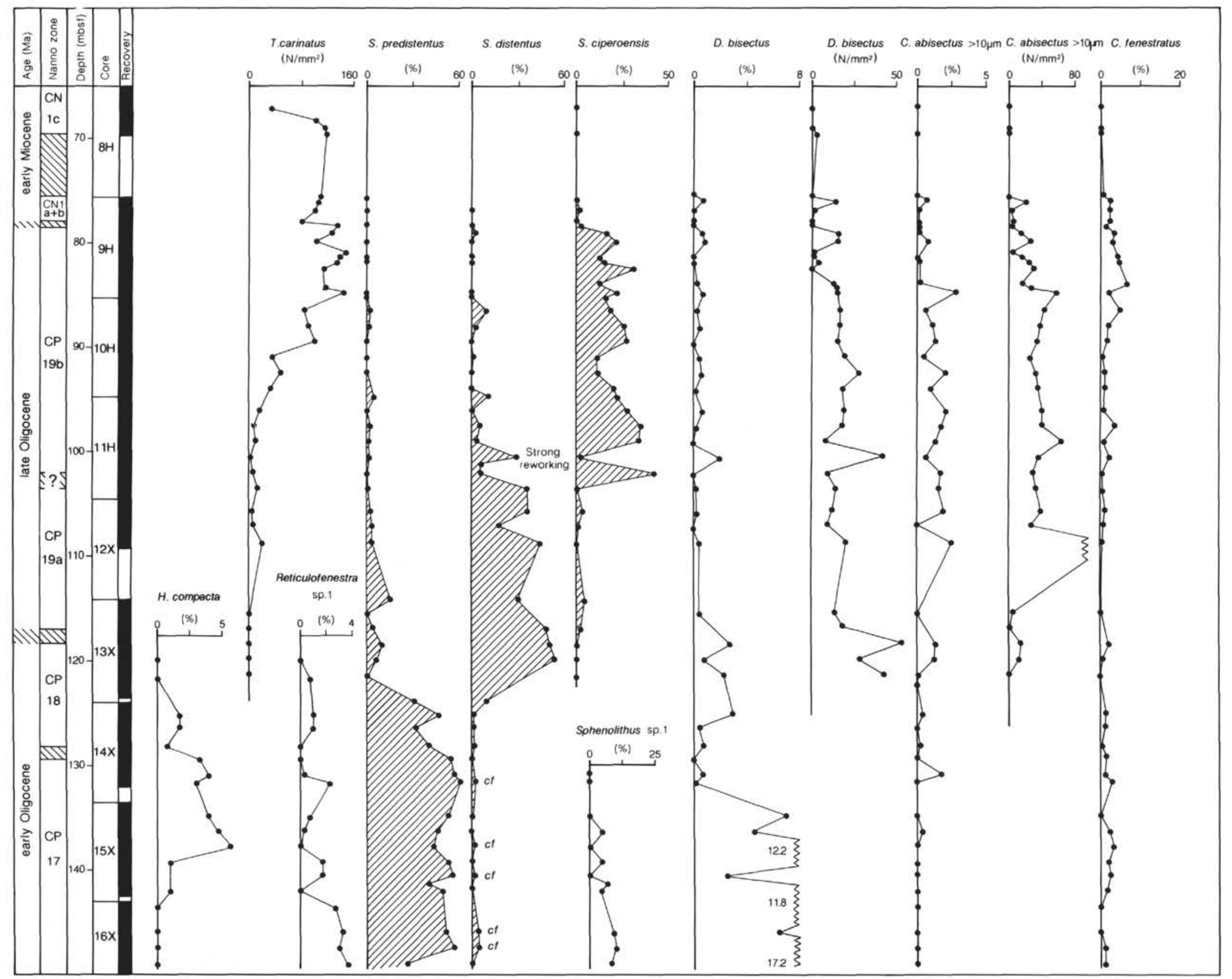




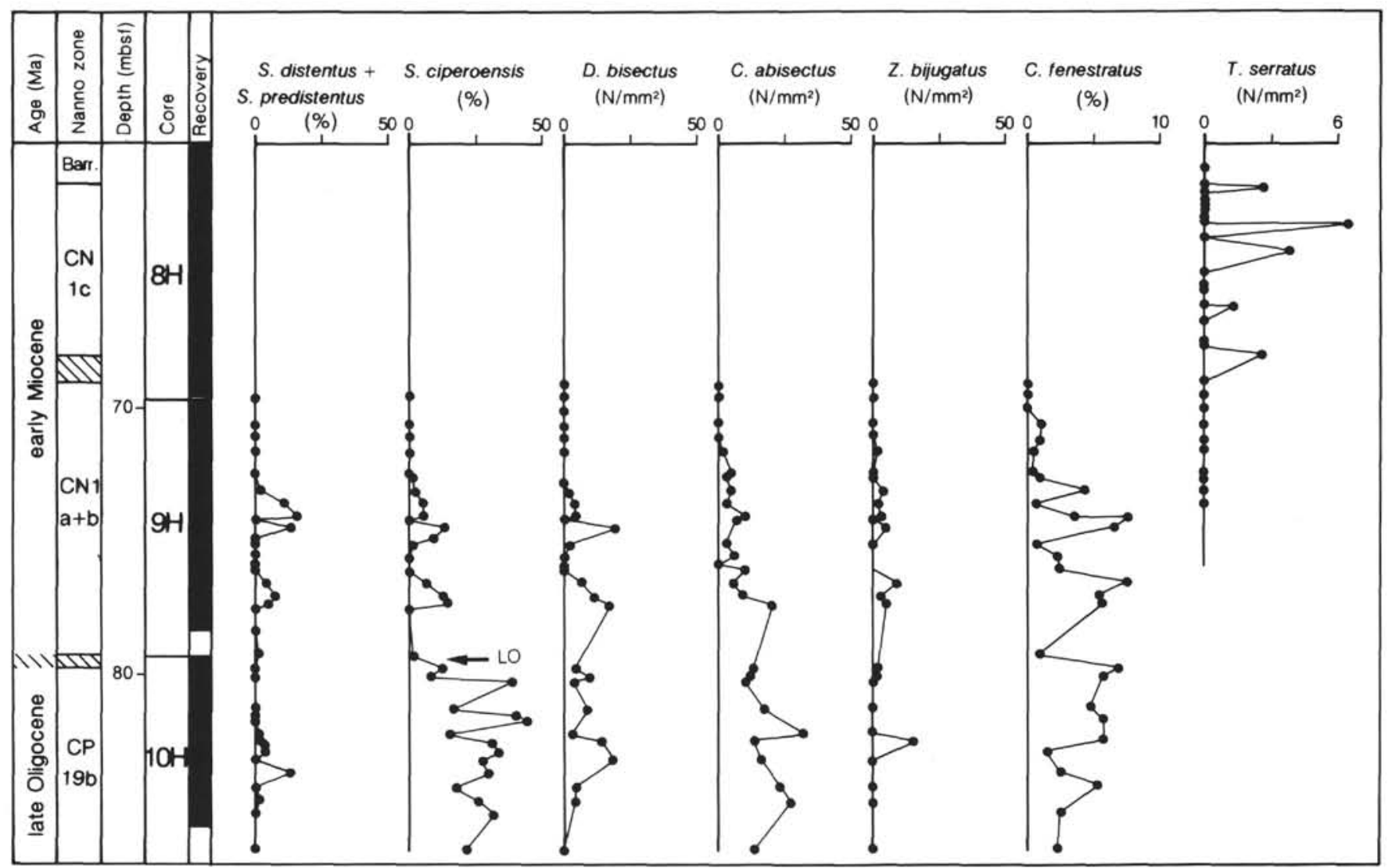

Figure 7. Abundance patterns of Oligocene and early Miocene sphenoliths and selected calcareous nannofossils at Hole $711 \mathrm{~B} . \mathrm{N} / \mathrm{mm}^{2}=$ number of specimens per square millimeter. See Figure 2 for counting methods.

investigated, $H$. compacta disappears below the FO of $S$. ciperoensis (i.e., in Zone NP23).

\section{The FO of Triquetrorhabdulus carinatus}

Triquetrorhabdulus carinatus is a major component of the late Oligocene-early Miocene sediments of the western equatorial Indian Ocean. Its extinction datum is discussed by Rio et al. (this volume). Here we document the early distribution of this species (Figs. 4-6 and 8-10). Both areal and total assemblage counts are shown. The results indicate that this form appeared in low abundance in the lower part of Zone NP24 (CP19a), as suggested previously by Biolzi et al. (1981) in sediments from the South Atlantic Ocean, and by Bizon and Müller (1979) in equatorial Pacific and equatorial Indian Ocean sediments. The distinct abundance increase in Zone NP25 (CP19b) may represent a potentially useful biostratigraphic indication.

\section{The $\mathbf{L O}$ of Dictyococcites bisectus}

The LO of $D$. bisectus has been widely used to recognize the top of Zone NP25 in sediments where $H$. recta is missing. Bukry (1973) proposed that this event can be used as a secondary event to recognize the top of Subzone CP19b. Berggren et al. (1985) suggested that the LO of $D$. bisectus provides a practical nannofossil criterion for recognition of the Oligocene/Miocene boundary.

The abundance patterns of $D$. bisectus in the equatorial Indian Ocean are shown in Figures 2-8. This species is quite abundant in the early Oligocene (Figs. 5 and 6), but it becomes less important in late Oligocene assemblages. Its final range is characterized by rare and discontinuous occurrences, thus making it difficult to discriminate between occurrences caused by low pro- ductivity and those caused by reworking. The present data, however, seem to indicate that the form becomes extinct close to the LO of S. ciperoensis, as indicated by Bizon and Müller (1979) at Site 237 (Mascarene Plateau).

Data in the literature indicate variable positions of the LO of $D$. bisectus relative to the $\mathrm{LO}$ of $S$. ciperoensis (e.g., Berggren et al., 1985). We consider that the biostratigraphic relationship between these two species, as observed in the equatorial Indian Ocean, is only of regional value. For example, our ongoing research in Mediterranean sequences indicates that $D$. bisectus disappears later than $S$. ciperoensis. Of these two events, the former appears to be the more likely candidate to show diachrony over geographic distance, judging from the few biomagnetostratigraphic correlations available.

\section{The LO of Clausicoccus fenestratus}

Bizon and Müller (1979) reported that $C$. fenestratus disappears together with $S$. ciperoensis, $D$. bisectus, and $H$. recta, close to the Oligocene/Miocene boundary in the Indian Ocean. The percentages of $C$. fenestratus, as obtained by counting 500 nannofossils, are shown in Figures 2-8. The form is never abundant, representing at most a few percent of the total assemblage, and seems to survive $S$. ciperoensis in practically all sequences considered.

\section{The LO of Zygrhablithus bijugatus}

The LO of $Z$. bijugatus has been proposed to approximate the top of Zone NP25, and therefore the Oligocene/Miocene boundary, in nearshore sequences (i.e., Martini and Müller, 1975; Müller, 1976). Zygrhablithus bijugatus occurs in low abundances in the investigated sequences, and is totally absent in the non- 


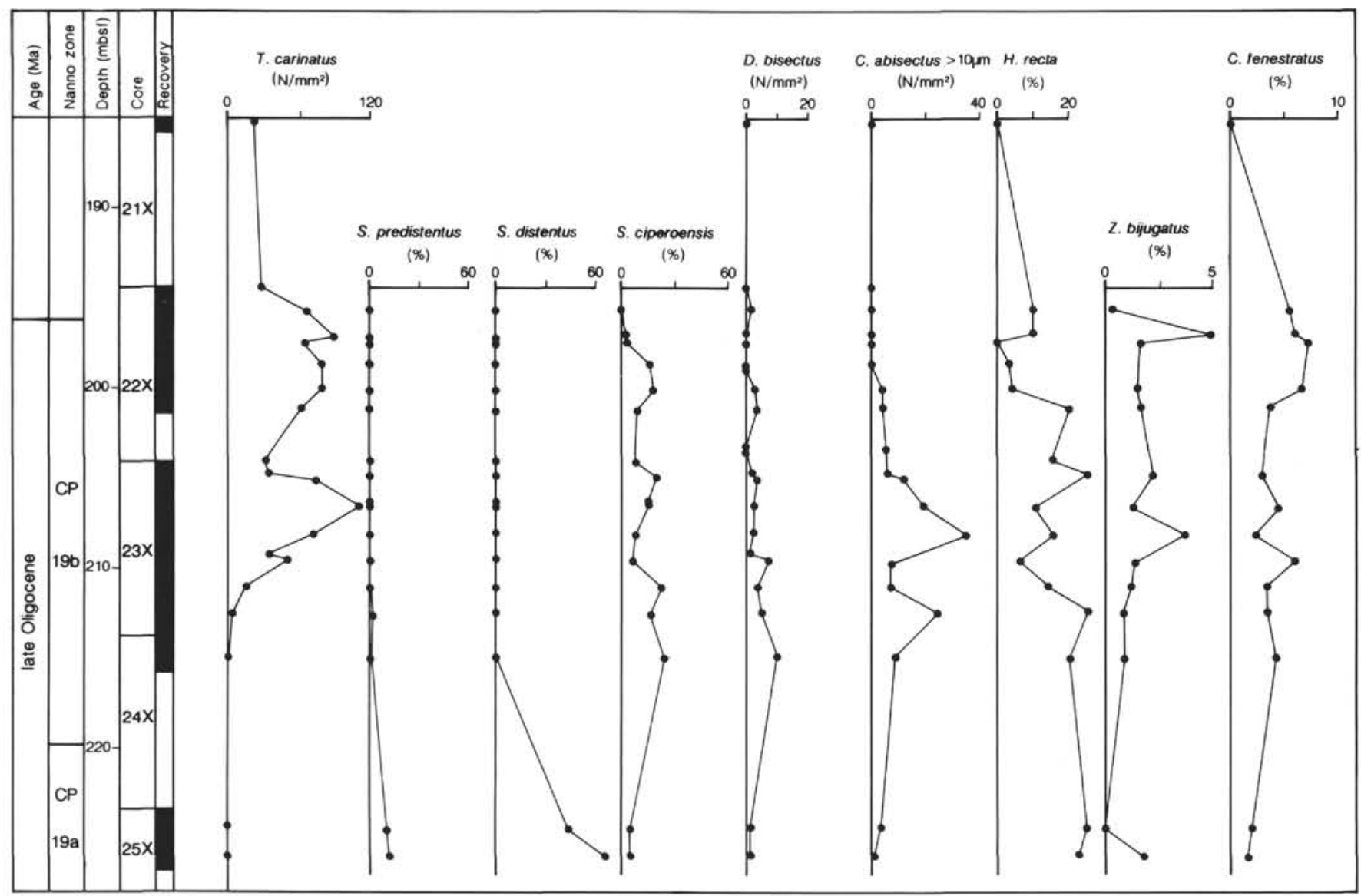

Figure 8. Abundance patterns of Oligocene sphenoliths and other selected calcareous nannofossils at Hole $714 \mathrm{~A} . \mathrm{N} / \mathrm{mm}^{2}=\mathrm{number}$ of specimens per square millimeter. The Helicosphaera recta percentages were obtained by counting 50 helicoliths. See Figure 2 for other counting methods.

turbiditic sediments of the deep-water sequence retrieved at Hole 711A. Its scarcity is probably related to ecologic controls, as the taxon is never common in open-ocean sediments, but it is certainly also related to preservational factors as its abundance decreases progressively with increasing water depth at the CBT sites (Figs. 2-5 and 7). Zygrhablithus bijugatus is a holococcolith, and the susceptibility of this simply constructed nannofossil to dissolution is well established (Wise and Wind, 1977; Wind and Wise, 1978). These factors, and the poor recovery in the critical interval at Site 714 , where the form is better represented, do not provide accurate assessments of the relationship between the LO of Z. bijugatus and other events that occur close to the Oligocene/Miocene boundary.

\section{The LO of Helicosphaera recta}

Helicoliths are rare or absent in upper Oligocene to middle Miocene sediments retrieved during Leg 115 except at Site 714 (Rio et al., this volume), where the percentages of $H$. recta were established through counts of 50 helicoliths (Fig. 8). This taxon seems to survive to the extinction of S. ciperoensis (Fig. 8), but the poor recovery in Core 115-714A-21X makes it impossible to estimate whether these two events are synchronous. Rio et al. (this volume) observed genuine $H$. recta in Zone NN4 at Sites 714 and 715, and Perch-Nielsen (1985) reported this species from sediments of early Miocene age. Because of the rare occurrences or absence of this taxon in open-ocean sediments, and because of its unknown precise range, we conclude that the LO of $H$. recta is of restricted value in biostratigraphy.

\section{MIOCENE BIOSTRATIGRAPHIC EVENTS}

\section{Early and Middle Miocene Sphenoliths}

The distribution of early and middle Miocene sphenoliths that are not commonly used for biostratigraphy, but which can be potentially useful, are shown in Figures 3-5 and 9-10. Specifically, we have tabulated the distribution of Sphenolithus conicus, $S$. delphix, $S$. capricornutus, $S$. multispinatus, $S$. pseudoheteromorphus, and $S$. milanetti. These forms are easily recognized in the optical microscope (Rio et al., in press and this volume).

Sphenolithus delphix (Plate 3, Fig. 7) is reported as being distributed from the late Oligocene to the early Miocene (PerchNielsen, 1985). In our material (Figs. 3-5 and 9), it is restricted to the upper part of the early Miocene Subzone CN1c, where it becomes very abundant. This acme interval is easily correlated in the western equatorial Indian Ocean (Rio et al., this volume).

Sphenolithus capricornutus (Plate 3, Fig. 5) is known to be distributed in sediments of late Oligocene and early Miocene age (Perch-Nielsen, 1985). We observed this species only in the early Miocene Subzone CN1c, associated with $S$. delphix (Fig. $4)$, with which it is probably conspecific.

Sphenolithus conicus (Plate 2, Fig. 4) is reported to be restricted to the early Miocene Zones NN1/NN3 (Perch-Nielsen, 1985). We have investigated the range of this form, which is consistently present in the early Miocene Zone CN1 and scattered in Zone CN2 (Figs. 4-5 and 9-10), in agreement with previous suggestions (Perch-Nielsen, 1985). 


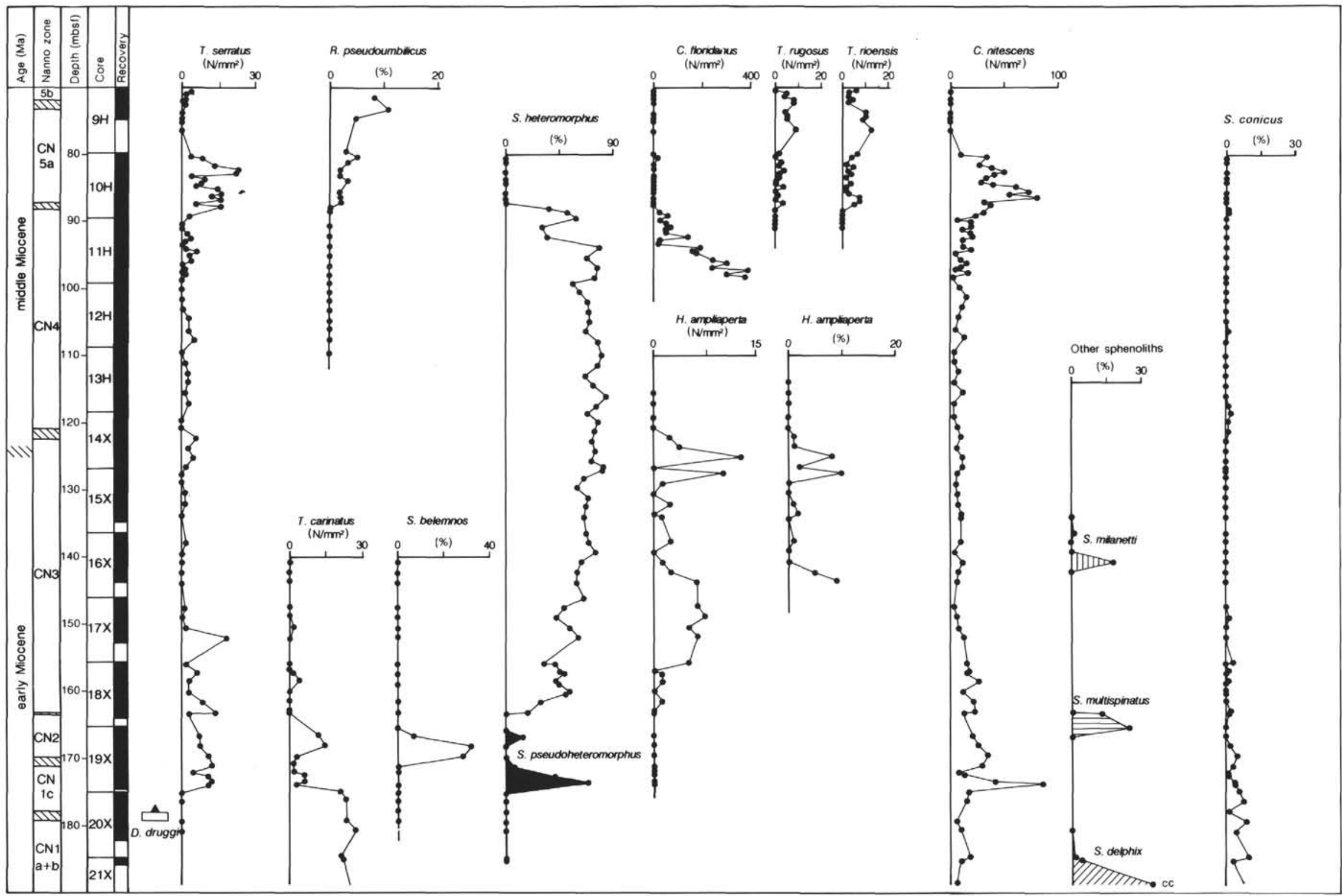

Figure 9. Abundance patterns of early and middle Miocene and selected calcareous nannofossils at Hole $714 \mathrm{~A} . \mathrm{N} / \mathrm{mm}^{2}=$ number of specimens per square millimeter. The Reticulofenestra pseudoumbilicus percentage is vs. the total nannofossil assemblage. Sphenolith and Helicosphaera ampliaperta percentages were obtained by counting 100 sphenoliths and 100 helicoliths, respectively. 


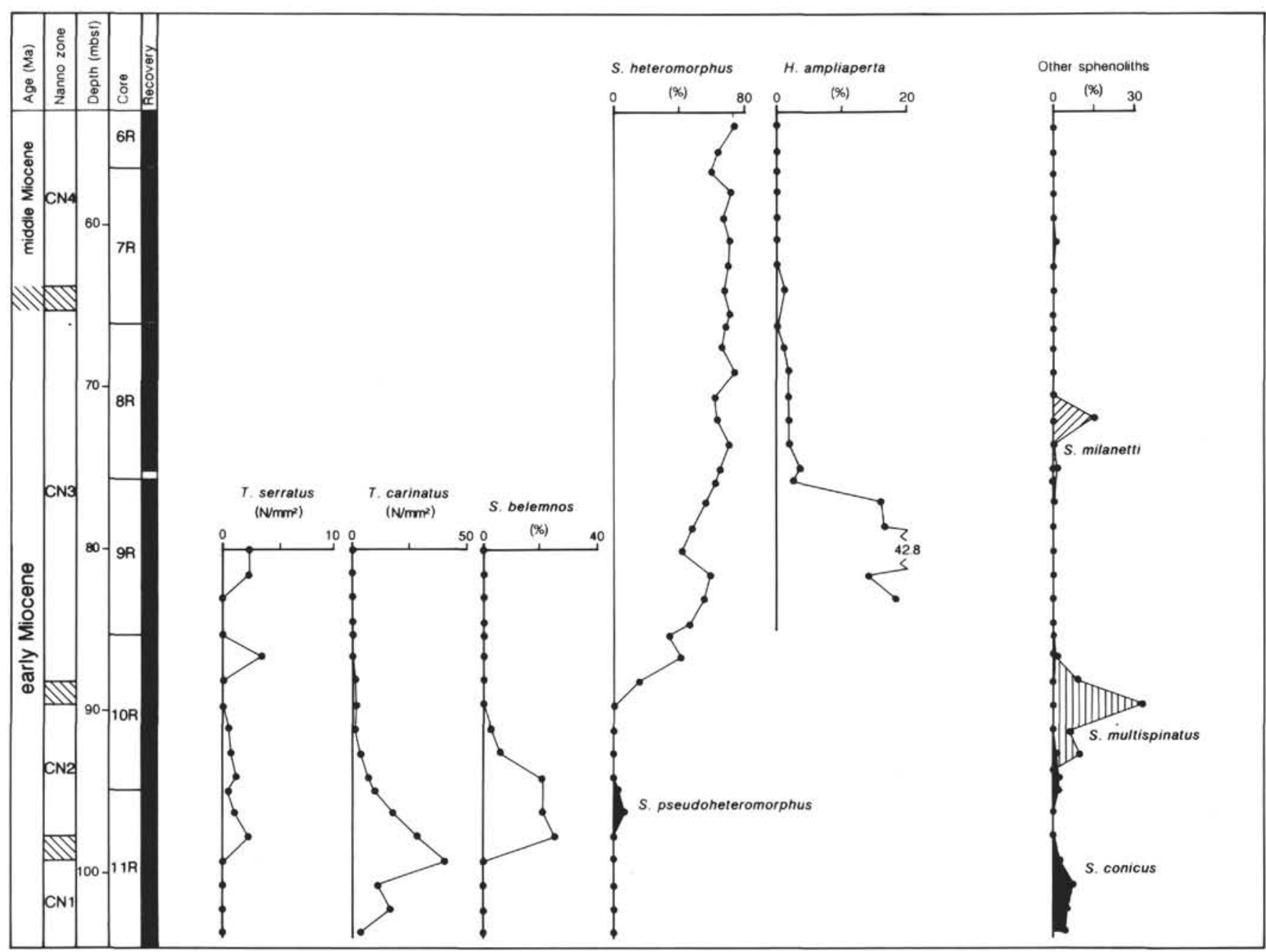

Figure 10. Abundance patterns of early and middle Miocene and selected calcareous nannofossils at Hole $715 . \mathrm{N} / \mathrm{mm}^{2}=$ number of specimens per square millimeter. Sphenoliths and Helicosphaera ampliaperta percentages were obtained by counting 100 sphenoliths and 100 helicoliths, respectively.

Sphenolithus pseudoheteromorphus (Plate 3, Fig. 4), which may have been confused with $S$. heteromorphus in the literature, has been observed to occur below and together with $S$. belemnos at Holes 714A and 715A (Figs. 9 and 10), but not to overlap with $S$. heteromorphus.

Sphenolithus multispinatus (Plate 3, Figs. 1-3) is restricted to a short interval straddling the $\mathrm{CN} 2 / \mathrm{CN} 3$ boundary (Figs. 9 and 10).

Sphenolithus milanetti (Plate 3, Fig. 6) is restricted to a very short interval within Zone CN3 (Figs. 9 and 10). Olafsson (1989) reported this species as Sphenolithus sp. 1 in the corresponding stratigraphic position in sediments from equatorial Atlantic Site 667.

\section{The FO of Triquetrorhabdulus serratus}

Bukry (1973) and Olafsson (1989) both propose that the FO of $T$. serratus is a good alternative event to the FO of Discoaster druggii for recognizing the base of Subzone CN1c. In Leg 115 sediments, the base of this interval was recognized by means of its formal definition (FO of D. druggii). In Figures 7, 9, and 10, we have plotted the distribution patterns of $T$. serratus at Sites 714 and 715 . This taxon occurs in low abundances $(<1 \%$ of the total assemblage) and does not yield good correlations among the Leg 115 sites (Rio et al., this volume). However, areal counts reported here suggest that its absolute $\mathrm{FO}$ occurs close to the $\mathrm{FO}$ of $D$. druggii, as suggested previously by Olafsson (1989) and Bukry (1973).

\section{The LO of Sphenolithus belemnos and FO of Sphenolithus heteromorphus}

The precise biostratigraphic relationship between the LO of $S$. belemnos and the FO of $S$. heteromorphus are still controversial. Bukry (1972) reported a co-occurrence of these two species at DSDP Site 140 in the Atlantic Ocean. The co-occurrence of these taxa was also reported by Takayama and Sato (1987) in the northern Atlantic and by Pujos (1985) in the equatorial Pacific. Olafsson (1989) found that the two species do not overlap at the eastern equatorial Atlantic Site 667. The distribution patterns of $S$. belemnos and $S$. heteromorphus at Sites 714 and 715 are shown in Figures 9 and 10. Our data indicate that the two forms do not overlap in the subtropical western Indian Ocean, in agreement with Olafsson (1989).

\section{The LO of Cyclicargolithus floridanus}

The LO of C. floridanus was proposed by Bukry (1973) as an alternative event to the FO of Discoaster kugleri for recognizing the base of Subzone CN5b. The former event has been reported to occur as high as Subzone CN5b (Miller et al., 1985; Roth and 
Thierstein, 1972). Olafsson (1989) reported the LO of C. floridanus within Zone CN5, some 2 m.y. after the LO of $S$. heteromorphus in the equatorial Atlantic Ocean. The Zone CN5 time interval is poorly represented in Leg 115 sediments because of hiatuses and strong dissolution (Rio et al., this volume), except at Site 714 in the Maldives region.

The abundance pattern of $C$. floridanus at Site 714 is shown in Figure 9. This species shows a sharp abundance decline before the LO of S. heteromorphus, and apparently disappears at the top of the Zone CN4. Taken together, these observations suggest that the LO of C. floridanus is diachronous over geographic distance and that it must be used with caution in biostratigraphy.

\section{The FO of Reticulofenestra pseudoumbilicus}

We have learned during the past decade that reticulofenestrid taxonomy is strongly dependent, among other criteria, on placolith size concepts. Not surprisingly, this has resulted in large differences in literature estimates of the FO of R. pseudoumbilicus. Martini (1971) reported its FO in the late Miocene Zone NN11. Bukry (1973) reported this event in the lower part of the middle Miocene Zone CN4, whereas Perch-Nielsen (1985) reported it in Subzone CN5b. We have plotted the initial distribution of $R$. pseudoumbilicus at Site 714 (Fig. 9) by applying the species concept used by Raffi and Rio (1979) and Backman and Shackleton (1983) when they evaluated its LO in the Pliocene (i.e., including only forms $>7 \mu \mathrm{m}$; see Rio et al., this volume). Our results indicate that forms $>7 \mu \mathrm{m}$ appear at the top of Zone CN4. The appearance of large $R$. pseudoumbilicus is concomitant with the disappearance of $C$. floridanus (Fig. 9).

\section{The FOs of Triquetrorhabdulus rugosus-Triquetrorhabdulus rioensis}

The initial and nearly simultaneous FOs of T. rugosus and $T$. rioensis are useful biostratigraphic events in both the equatorial Atlantic and Pacific oceans (Olafsson, 1989). Both events occur close to the LO of $S$. heteromorphus. The initial range of these two forms at Site 714 is plotted in Figure 9. The resulting distribution pattern is coherent with the one established by Olafsson (1989), which emphasizes the usefulness of these events in equatorial regions at least.

\section{The Subdivision of Middle Miocene Zone CN5 (NN6/NN7)}

The FO of Discoaster kugleri defines the $\mathrm{CN} 5 \mathrm{a} / \mathrm{CN} 5 \mathrm{~b}$ and the NN6/NN7 boundaries. This event is difficult to establish precisely because of taxonomic difficulties involving the presence of atypical specimens, most probably related to Discoaster musicus, and because of the discontinuous distribution of $D$. kugleri. The FO of $D$. kugleri is considered as a less reliable biostratigraphic indication also in previous studies (i.e., Gartner and Chow, 1985), and alternative criteria have been proposed to subdivide the CN5 (NN6/NN7) zonal interval: the LO of Cyclicargolithus floridanus (Bukry, 1973), the FO of Discoaster bollii (Ellis, 1981), and the LO of Coronocyclus nitescens (Gartner and Chow, 1985). Of these three events, the LO of $C$. floridanus is discussed above. The $\mathrm{LO}$ of $C$. nitescens and the FO of Calcidiscus macintyrei are discussed below, with reference to the results obtained in Hole 714B (Fig. 11), where the CN5 interval is well represented and completely recovered.

\section{The LO of Coronocyclus nitescens}

The final range of $C$. nitescens in Hole 714B is shown in Figure 11. Its extinction was examined by counting its abundance per unit area, as well as by determining its percentage in a tally of 500 nannofossils. The two methods provide identical bio- stratigraphic results, indicating that the LO of $C$. nitescens is a well-defined event that is useful in subdividing the late middle Miocene interval between the LO of S. heteromorphus and the FO of Catinaster coalitus.

\section{The FO of Calcidiscus macintyrei}

Backman and Shackleton (1983) proposed that the distal shield diameter is a practical means for separating $C$. macintyrei from Calcidiscus leptoporus. They indicated $10 \mu \mathrm{m}$ as the critical size limit to make the distinction between the two species. The results of a biometric analysis of placolith size carried out close to the LO of C. macintyrei in cores from different areas are shown in Figure 12. This shows a distinct bimodal distribution and supports the conclusion of Backman and Shackleton (1983). The results of a similar biometric analysis, based on counts of 50 specimens of Calcidiscus per sample from the middle Miocene of Site 714, are shown in Figure 13. The bimodal size distribution that characterized the Pliocene-Pleistocene interval (Fig. 12) is not present in the middle Miocene. Morphotypes $10 \mu \mathrm{m}$ in size are consistently present in the middle Miocene populations (Fig. 13), whereas they are almost completely missing in late Pliocene-early Pleistocene (Fig. 12). The size of the Calcidiscus population, however, increased as a function of time (Fig. 13). If we restrict the Miocene concept of $C$. macintyrei to forms $>11 \mu \mathrm{m}$, its FO can be determined to the interval between the FOs of $D$. kugleri and $C$. coalitus. Similarly, in other Leg 115 sites, the appearance of Calcidiscus $>11 \mu \mathrm{m}$ seems to occur in the late CN5 Zone (Rio et al., this volume).

\section{REMARKS ON BIOMAGNETOCHRONOLOGY}

Of the 12 sites drilled during Leg 115 , only two yielded adequate Miocene-Oligocene magnetostratigraphic data from the sedimentary records (Schneider and Kent, this volume). Most of the Miocene, and Oligocene/Miocene boundary, nannofossil events discussed above have been calibrated to the magnetostratigraphies obtained from Sites 710 and 711 (Backman et al., this volume). Most of the remaining events discussed here are derived from sites lacking magnetostratigraphy, and these events are thus omitted from this discussion. The (Miocene) exception to this is the acme interval of Sphenolithus delphix, which has an age range of 23.6-24.7 Ma, according to the age model established at Site 710 (Peterson and Backman, this volume).

The Oligocene magnetostratigraphy obtained from Site 711 ended in an interval of normal polarity, which is interpreted as Chron C9N, at about $28.5 \mathrm{Ma}$. This implies that we lack age estimates based on direct bio- and magnetostratigraphic calibrations for the following Oligocene nannofossil events (which all occur before $28.5 \mathrm{Ma}$ ): the LOs of Helicosphaera compacta, Reticulofenestra sp. 1, and Sphenolithus sp. 1, the FOs of Triquetrorhabdulus carinatus, Sphenolithus distentus, Sphenolithus ciperoensis, and Cyclicargolithus abisectus, and the shift in dominance between $S$. predistentus and $S$. distentus.

Direct calibration between nannofossil biostratigraphy and Oligocene magnetostratigraphy can thus be achieved only for two events, namely the distinct rise in abundance of $T$. carinatus and the shift in dominance between $S$. distentus and $S$. ciperoensis. The former event occurs in the upper part of Chron C8N, at about $27.0 \mathrm{Ma}$. The latter transition is associated with upper Chron C9N. Extrapolation of the sedimentation rate between the onset of Chron C7N2 (25.97 Ma) and the termination of Chron C9N1 (28.15 Ma) gives an age of about $28.8 \mathrm{Ma}$ for the abundance shift of these two sphenolith species. In this context, it should be pointed out that Peterson and Backman (this volume) argue for an age of about 27.4-27.5 Ma for the absolute LO of S. distentus. 


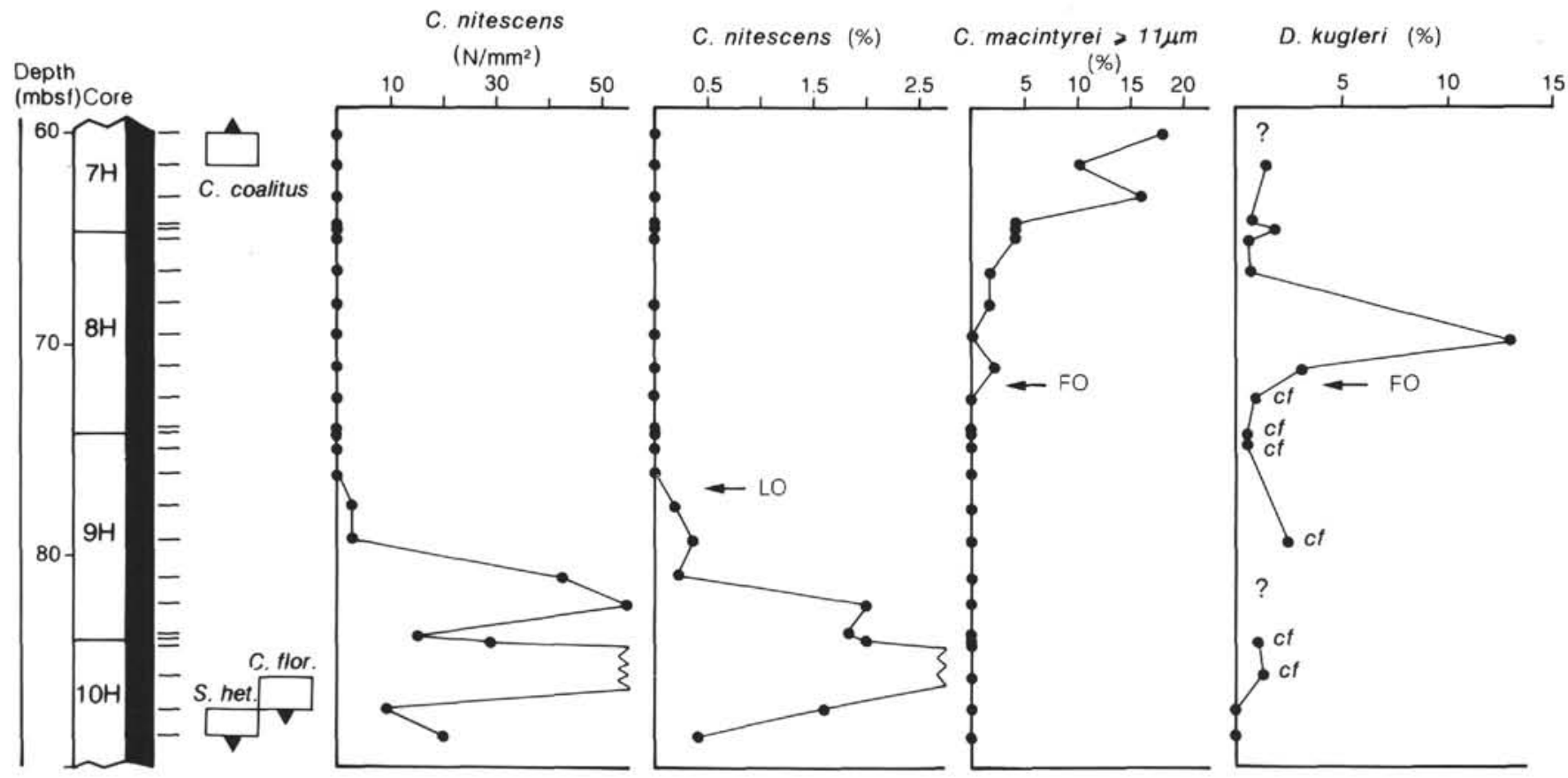

Figure 11. Calcareous nannofossil events in the CN5 zonal interval of Hole 714B. Percentages of $C$. macintyrei and $D$. kugleri were obtained by counting 50 Calcidiscus and 200 Discoaster specimens, respectively.

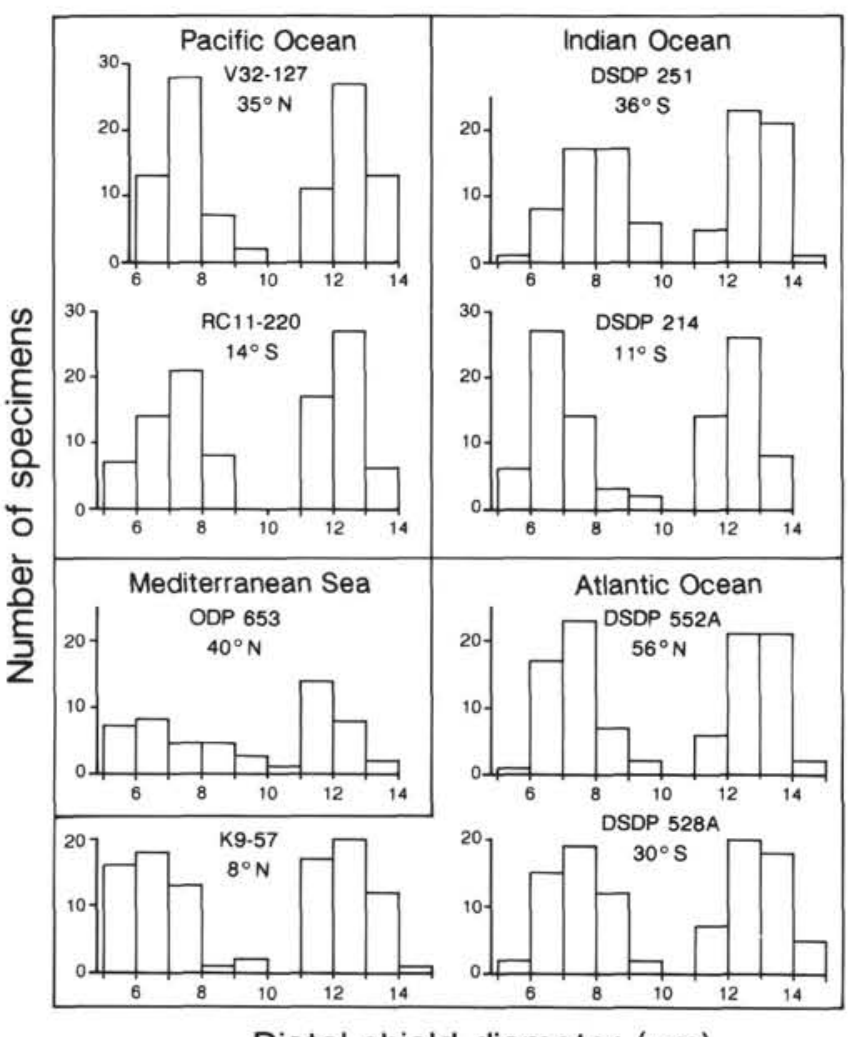

Distal shield diameter $(\mu \mathrm{m})$

Figure 12. Distal shield diameters of Calcidiscus in samples from different areas during late Pliocene-early Pleistocene time.

\section{CONCLUSIONS}

Quantitative distribution patterns of selected calcareous nannofossils were determined in Oligocene and Miocene sediments from the western equatorial Indian Ocean. Our main goal was to establish a preliminary data base as a reference for future similar studies in other areas. Only when further documentation becomes available, will it be possible to evaluate fully the biostratigraphic potential of the forms considered here.

The following conclusions, therefore, are to be considered as preliminary. During the Oligocene, the successive FO of Sphenolithus ciperoensis and the LOs of Sphenolithus distentus (concomitant with the exit of Sphenolithus predistentus and the increase in abundance of $S$. ciperoensis) and $S$. ciperoensis provide good biostratigraphic signals. Distinct shifts in dominance in the Oligocene $S$. predistentus-S. ciperoensis lineage are considered to provide better marker events than those conventionally used. First, the change from dominant $S$. predistentus to dominant $S$. distentus appears more reliable than the FO of the latter species for determination of the CP17/CP18 boundary, or when subdividing NP23. Second, the change from dominant $S$. distentus to dominant $S$. ciperoensis, at about $28.8 \mathrm{Ma}$, is clearly a better event than the $\mathrm{LO}$ of the former species for recognition of the NP24/NP25 (CP19a/CP19b) boundary, which may occur as late as $27.4 \mathrm{Ma}$. Other Oligocene events (the FO of Cyclicargolithus abisectus $>10 \mu \mathrm{m}$, the LO of Dictyococcites bisectus, and the FO of Triquetrorhabdulus carinatus) are more difficult to determine precisely. A distinct rise in abundance of $T$. carinatus, however, is considered as a potentially useful datum. This event is estimated to occur at about $27.0 \mathrm{Ma}$.

The marker species for the NP25/NN1 boundary, Helicosphaera recta, is absent or rare in the late Oligocene. Rare occurrences were observed also in the early middle Miocene. Its LO is considered to be a poor biostratigraphic event.

Sphenolithus delphix is restricted to the early Miocene (CN1aCN1b, NN1), where it is abundant between 23.6 and 24.7 Ma. This distinct acme interval is easily correlated within the equato- 

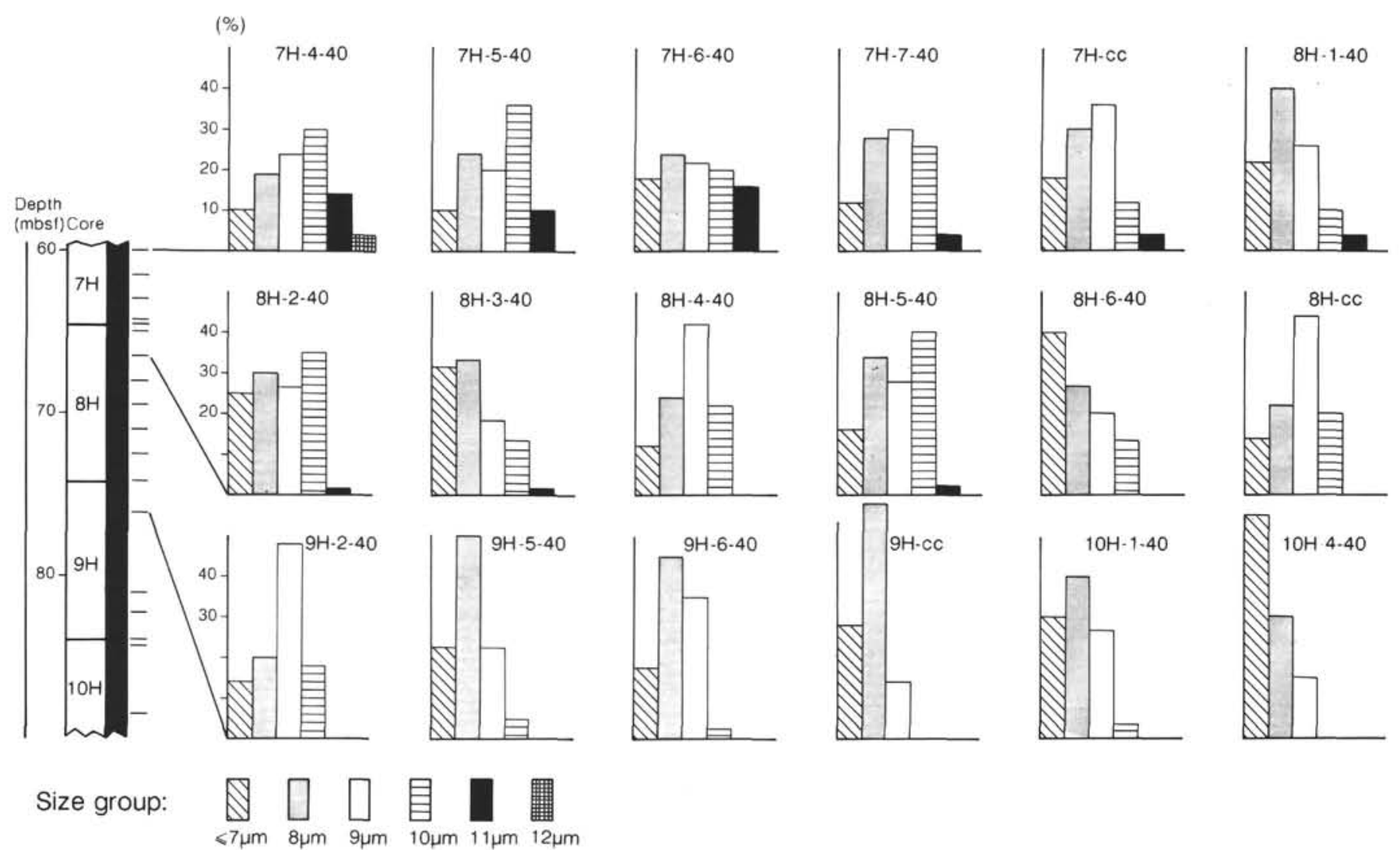

Figure 13. Distal shield diameters of Calcidiscus in the middle Miocene at Hole 714B.

rial Indian Ocean, where it provides a useful biostratigraphical event. Presently, it is not known if this acme interval is preserved in other regions. Considering the poor resolution of early Miocene biochronology, the potential use of the $S$. delphix acme becomes important and deserves to be investigated from other ocean basins and latitudes. The acme of $S$. delphix also has the potential to replace the formal $\mathrm{CN} 1 \mathrm{a}-\mathrm{CN} 1 \mathrm{~b}$ definition (end acme C. abisectus), which was originally used by Bukry in his low-latitude zonation, but which has never been defined quantitatively and which could not be observed in our counts of $C$. abisectus across the critical interval.

The biostratigraphic ranges of Sphenolithus belemnos and Sphenolithus heteromorphus do not overlap in the western equatorial Indian Ocean. Morphotypes similar to $S$. heteromorphus (S. pseudoheteromorphus), however, co-occurred with $S$. belemnos, which may help explain previous reports of overlapping ranges. Several events occur close to the $\mathrm{LO}$ of $S$. heteromorphus (which provides a distinct event in the study area): the nearly simultaneous appearance of Triquetrorhabdulus rugosus and Triquetrorhabdulus rioensis, the FO of Reticulofenestra pseudoumbilicus and the LO of Cyclicargolithus floridanus. A distinct LO of Coronocyclus nitescens was observed in the interval between the LO of $S$. heteromorphus and the FO of Catinaster coalitus. The LO of $C$. nitescens seems to be a better event than the FO of Discoaster kugleri for subdividing the CN5 (NN6-NN7) zonal interval.

Biometric analysis of the distal shield diameter of Calcidiscus populations from sediments of late Pliocene and middle Miocene ages, respectively, results in a clear bimodal distribution during late Pliocene times. The Miocene populations are clearly unimodal. If we tentatively define $C$. macintyrei as a morphotype $>11 \mu \mathrm{m}$, its Miocene FO is observed in the late part of the Subzone CN5b.

\section{ACKNOWLEDGMENTS}

The constructive criticism provided by two anonymous reviewers is greatly appreciated. Financial support was provided by CNRS, NFR, and the universities of Parma, Padova, and Stockholm.

\section{REFERENCES}

Backman, J., 1987. Quantitative calcareous nannofossil biochronology of middle Eocene through early Oligocene sediment from DSDP Sites 522 and 523. Abh. Geol. Bundesanst. (Austria), 39:21-32.

Backman, J., Duncan, R. A., et al., 1988. Proc. ODP, Init. Repts., 115: College Station, TX (Ocean Drilling Program).

Backman, J., and Shackleton, N. J., 1983. Quantitative biochronology of Pliocene and early Pleistocene calcareous nannoplankton from the Atlantic, Indian and Pacific oceans. Mar. Micropaleontol., 8: $141-170$.

Berggren, W. A., Kent, D. V., and Van Couvering, J. A., 1985. The Neogene: Part 2, Neogene geochronology and chronostratigraphy. In Snelling, N. J. (Ed.), The Chronology of the Geological Record. Geol. Soc. Mem. (London), 10:211-260.

Biolzi, M., Perch-Nielsen, K., and Ramos, I., 1981. Triquetrorhabdulus - an Oligocene/Miocene calcareous nannofossil genus. Int. Nannoplankton Assoc. Newsl., 3:89-92.

Bizon, G., and Müller, C., 1979. Remarks on the Oligocene/Miocene boundary based on the results obtained from the Pacific and the Indian Oceans. Ann. Geol. Pays Hell., 1:101-111.

Bramlette, M. N., and Wilcoxon, J. A., 1967. Middle Tertiary calcareous nannoplankton of the Cipero Section, Trinidad, W.I. Tulane Stud. Geol., 5:93-132.

Bukry, D., 1971. Coccolith stratigraphy Leg 6, Deep Sea Drilling Project. In Fischer, A. G., Heezen, B. C., et al., Init. Repts. DSDP, 6: Washington (U.S. Govt. Printing Office), 965-1004.

1972. Coccolith stratigraphy-Leg 14, Deep Sea Drilling Project. In Hayes, D. E., Pimm, A. C., et al., Init. Repts. DSDP, 14: Washington (U.S. Govt. Printing Office), 487-494. 
1973. Low-latitude coccolith biostratigraphic zonation. In Edgard, N. T., Saunders, J. B., et al., Init. Repts. DSDP, 15: Washington (U.S. Govt. Printing Office), 685-703.

1975. Coccolith and silicoflagellate stratigraphy, northwestern Pacific Ocean, Deep Sea Drilling Project Leg 32. In Larson, R. L., Moberly, R., et al., Init. Repts. DSDP, 32: Washington (U.S. Govt. Printing Office), 677-701.

Ellis, C. H., 1981. Calcareous nannoplankton biostratigraphy-Deep Sea Drilling Project Leg 60. In Hussong, D. H., Uyeda, S., et al., Init. Repts. DSDP, 60: Washington (U.S. Govt. Printing Office), 507-533.

Gartner, S., and Chow, J., 1985. Calcareous nannofossil biostratigraphy, Deep Sea Drilling Project Leg 85, eastern equatorial Pacific. In Mayer, L., Theyer, F., Thomas, E., et al., Init. Repts. DSDP, 85: Washington (U.S. Govt. Printing Office), 609-619.

Huang, T. C., 1977. Calcareous nannoplankton stratigraphy of the upper Wulai Group (Oligocene) in northern Taiwan. Pet. Geol. Taiwan, 14:147-179.

Loeblich, A. R., and Tappan, H., 1966. Annotated index and bibliography of the calcareous nannoplankton I. Phycologia, 5:81-216. , 1968. Annotated index and bibliography of the calcareous nannoplankton II. J. Paleontol., 42:584-598.

1969. Annotated index and bibliography of the calcareous nannoplankton III. J. Paleontol., 43:568-588.

,1970a. Annotated index and bibliography of the calcareous nannoplankton IV. J. Paleontol., 44:558-574.

, 1970b. Annotated index and bibliography of the calcareous nannoplankton V. Phycologia, 9:157-174.

, 1971. Annotated index and bibliography of the calcareous nannoplankton VI. Phycologia, 10:315-339.

, 1973. Annotated index and bibliography of the calcareous nannoplankton VII. J. Paleontol., 47:715-759.

Martini, E., 1971. Standard Tertiary and Quaternary calcareous nannoplankton zonation. In Farinacci, A. (Ed.), Proceedings of the Second International Conference on Planktonic Microfossils, Roma: Rome (Tecnoscienza), 739-785.

Martini, E., and Müller, C., 1975. Calcareous nannoplankton from the type Chattian (Upper Oligocene). 6th Congr. Reg. Comm. Mediterr. Neogene Stratigr. Proc. (Bratislava), 1:37-41.

1986. Current Tertiary and Quaternary calcareous nannoplankton stratigraphy and correlation. Newsl. Stratigr., 16:99-112.

Miller, K. G., Aubry, M.-P., Khan, K. J., Melillo, A. J., Kent, D. V., and Berggren, W. A., 1985. Oligocene-Miocene biostratigraphy, magnetostratigraphy and isotopic stratigraphy of the western North Atlantic. Geology, 13:257-261.

Müller, C., 1976. Tertiary and Quaternary calcareous nannoplankton in the Norwegian-Greenland Sea, DSDP, Leg 38. In Talwani, M., Udintsev, G., et al., Init. Repts. DSDP, 38: Washington (U.S. Govt. Printing Office), 823-841.

Okada, H., and Bukry, D., 1980. Supplementary modification and introduction of code numbers to the low-latitude coccolith biostratigraphic zonation (Bukry, 1973; 1975). Mar. Micropaleontol., 5:321325.

Olafsson, G., 1989. Quantitative calcareous nannofossil biostratigraphy of upper Oligocene to middle Miocene sediment from ODP Hole 667A and middle Miocene sediment from DSDP Site 574. In Ruddimann, W. F., Sarnthein, M., et al., Proc. ODP, Sci. Results, 108: College Station, TX (Ocean Drilling Program), 9-22.

Perch-Nielsen, K., 1985. Cenozoic calcareous nannofossils. In Bolli, H. M., Saunders, J. B., and Perch-Nielsen, K. (Eds.), Plankton Stratigraphy: Cambridge (Cambridge Univ. Press), 427-553.

Prins, B., 1979. Notes on nannology-1. Clausicoccus, a new genus of fossil coccolithophorids. Int. Nannoplankton Assoc. Newsl., 1(1): N2-N4.

Pujos, A., 1985. Cenozoic nannofossils, central equatorial Pacific, Deep Sea Drilling Project Leg 85. In Mayer, L., Theyer, F., Thomas, E., et al., Init. Repts. DSDP, 85: Washington (U.S. Govt. Printing Office), 581-608.

Raffi, I., and Rio, D., 1979. Calcareous nannofossil biostratigraphy of DSDP Site 132-Leg 13 (Tyrrhenian Sea-Western Mediterranean). Riv. Ital. Paleontol. Stratigr., 85:127-172.

Rio, D., Fornaciari, E., and Olafsson, G., in press. New Miocene calcareous nannofossil species from tropical Indian Ocean. Mem. Sci. Geol.

Rio, D., Raffi, I., and Villa, G., 1989. Pliocene-Pleistocene calcareous nannofossil distribution patterns in the western Mediterranean. In
Kastens, K., Mascle, J., et al., Proc. ODP, Sci. Results, 107: College Station, TX (Ocean Drilling Program), 513-533.

Roth, P. H., and Thierstein, H., 1972. Calcareous nannoplankton: Leg 14 of the Deep Sea Drilling Project. In Hayes, D. E., Pimm, A. C., et al., Init. Repts. DSDP, 14: Washington (U.S. Govt. Printing Office), 421-485.

Takayama, T., and Sato, T., 1987. Coccolith biostratigraphy of the North Atlantic Ocean, Deep Sea Drilling Project Leg 94. In Ruddiman, W. F., Kidd, R. B., Thomas, E., et al., Init. Repts. DSDP, 94, Pt. 2: Washington (U.S. Govt. Printing Office), 651-702.

Van Heck, S., 1979a. Bibliography and taxa of calcareous nannoplankton. Int. Nannoplankton Assoc. Newsl., 1(1):AB1-B27.

$1979 \mathrm{~b}$. Bibliography and taxa of calcareous nannoplankton. Int. Nannoplankton Assoc. Newsl., 1(2):13-42.

1980a. Bibliography and taxa of calcareous nannoplankton. Int. Nannoplankton Assoc. Newsl., 2(1):54-34.

$1980 \mathrm{~b}$. Bibliography and taxa of calcareous nannoplankton. Int. Nannoplankton Assoc. Newsl., 2(2):43-81.

1981a. Bibliography and taxa of calcareous nannoplankton. Int. Nannoplankton Assoc. Newsl., 3(1):4-41.

1981b. Bibliography and taxa of calcareous nannoplankton. Int. Nannoplankton Assoc. Newsl., 3(2):51-86.

1982a. Bibliography and taxa of calcareous nannoplankton. Int. Nannoplankton Assoc. Newsl., 4(1):7-50.

1982b. Bibliography and taxa of calcareous nannoplankton. Int. Nannoplankton Assoc. Newsl., 4(2):65-96.

Wind, F. H., and Wise, S. W., Jr. 1978. Mesozoic holococcoliths. Geology, 6:140-142.

Wise, S. W., Jr., and Wind, F. H., 1977. Mesozoic and Cenozoic calcareous nannofossils recovered by DSDP Leg 36 drilling on the Falkland Plateau, southwest Atlantic sector of the Southern Ocean. In Barker, P. F., Dalziel, I.W.D. et al., Init. Repts. DSDP, 36: Washington (U.S. Govt. Printing Office), 269-491.

Date of initial receipt: 13 July 1989

Date of acceptance: 18 December 1989

Ms 115B-153

\section{TAXONOMIC LIST}

Oligocene nannofossils considered in this chapter.

Cyclicargolithus abisectus (Müller, 1970) Wise, 1973

Zygrhablithus bijugatus (Deflandre in Deflandre and Fert, 1954) Deflandre, 1959

Dictyococcites bisectus (Hay, Mohler and Wade, 1966) Bukry and Percival, 1971

Triquetrorhabdulus carinatus Martini, 1965

Sphenolithus ciperoensis Bramlette and Wilcoxon, 1967

Helicosphaera compacta Bramlette and Wilcoxon, 1967

Sphenolithus distentus (Martini, 1965) Bramlette and Wilcoxon, 1967

Clausicoccus fenestratus (Deflandre and Fert, 1954) Prins, 1979

Sphenolithus predistentus Bramlette and Wilcoxon, 1967

Helicosphaera recta $\mathrm{Haq}, 1966$

Reticulofenestra sp. 1 (Plate 2, Figs. 8-9)

Sphenolithus sp. 1 (Plate 2, Figs. 1-3)

Miocene nannofossils considered in this chapter.

Sphenolithus belemnos Bramlette and Wilcoxon, 1967

Sphenolithus capricornutus Bukry and Percival, 1971

Sphenolithus conicus Bukry, 1971

Sphenolithus delphix Bukry, 1973

Cyclicargolithus floridanus (Roth and Hay in Hay et al., 1967) Bukry, 1971

Sphenolithus heteromorphus Deflandre, 1953

Discoaster kugleri Martini and Bramlette, 1963

Calcidiscus macintyrei (Bukry and Bramlette, 1969) Loeblich and Tappan, 1978

Sphenolithus milanetti Olafsson and Rio, in press

Sphenolithus multispinatus Fornaciari and Rio, in press

Coronocyclus nitescens (Kamptner, 1963) Bramlette and Wilcoxon, 1967

Sphenolithus pseudoheteromorphus Fornaciari and Rio, in press

Reticulofenestra pseudoumbilicus (Gartner, 1967) Gartner, 1969

Triquetrorhabdulus rioensis Olafsson, 1989

Triquetrorhabdulus rugosus Bramlette and Wilcoxon, 1967

Triquetrorhabdulus serratus (Bramlette and Wilcoxon, 1967) Olafsson, 1989 


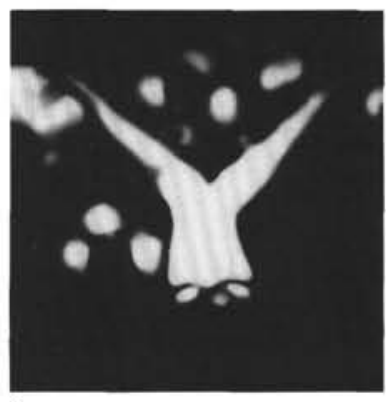

1

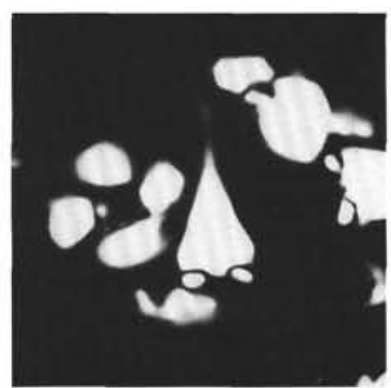

4

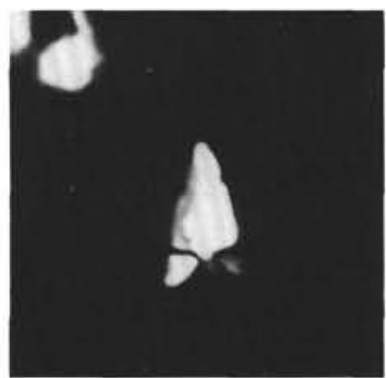

7

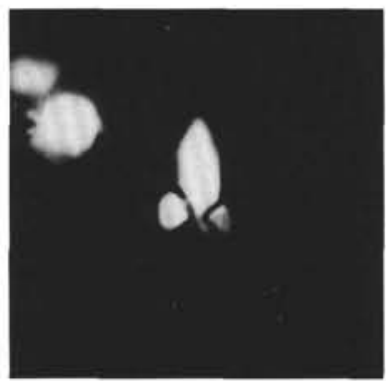

$11 \mathrm{~A}$

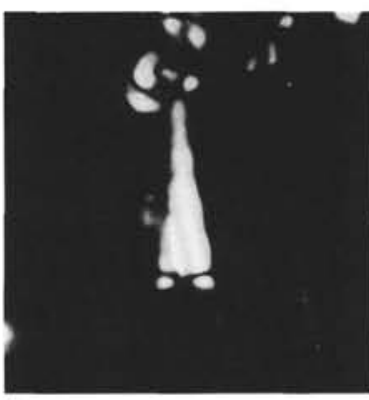

2

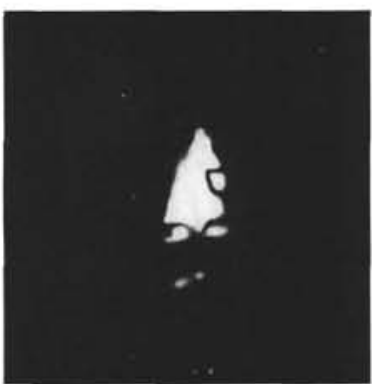

5

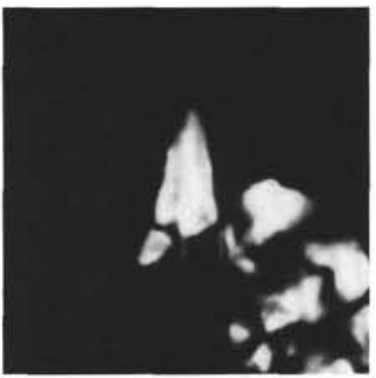

8

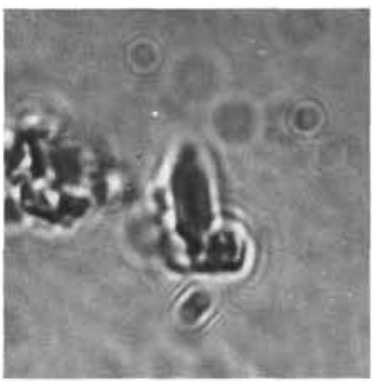

11B

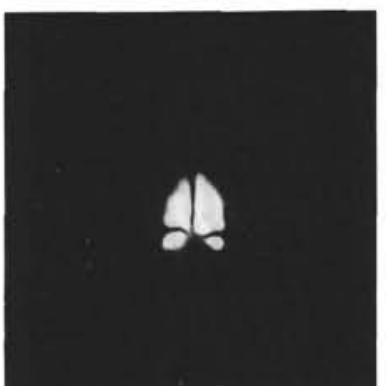

3A

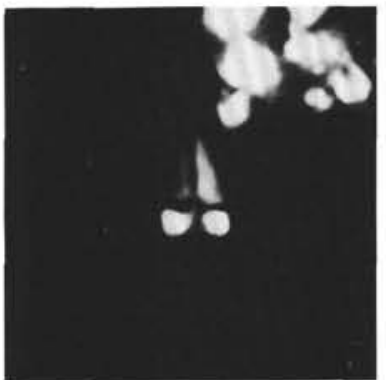

$6 \mathrm{~A}$

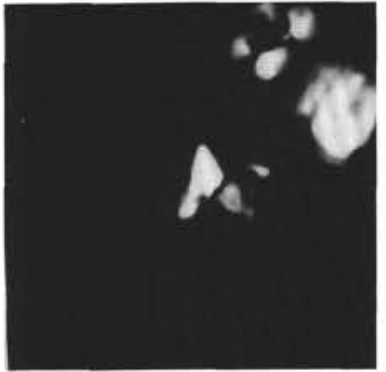

9

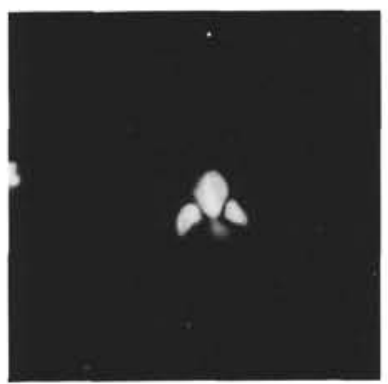

12

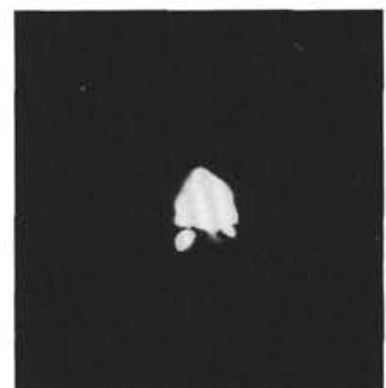

3B

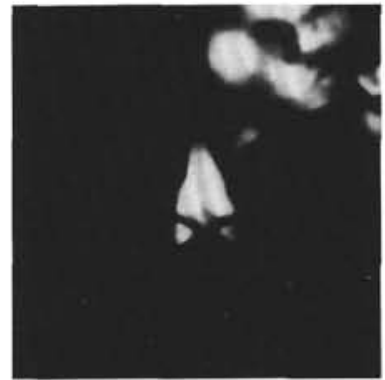

$6 B$

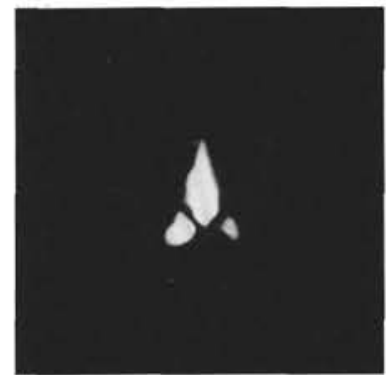

10

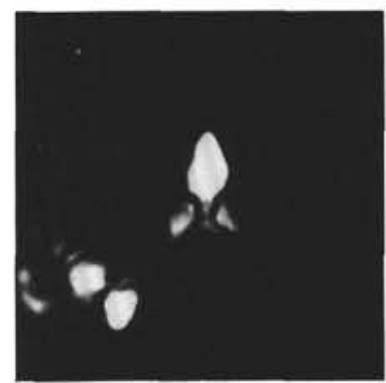

13

Plate 1. All specimens $\times 2400$. 1-5. Sphenolithus predistentus Bramlette and Wilcoxon. (1) Sample $115-710 \mathrm{~A}-21 \mathrm{X}-5,130 \mathrm{~cm}$; long axis $45^{\circ}$ to crossed nicols. (2) Sample 115-708A-23X-1, $130 \mathrm{~cm}$; long axis $45^{\circ}$ to crossed nicols. (3) and (4) Sample 115-710A-21X-1, $100 \mathrm{~cm}$. (3a) Long axis $0^{\circ}$ to crossed nicols. (3b) and (4) Long axis $45^{\circ}$ to crossed nicols. (5) Sample 115-710A-21X-6, $130 \mathrm{~cm}$; long axis $45^{\circ}$ to crossed nicols. 6-10. Sphenolithus distentus (Martini). (6), (7), and (8) Sample 115-709C-25X-3, $60 \mathrm{~cm}$. (6a) Long axis $0^{\circ}$ to crossed nicols. (6b), (7), and (8) long axis $45^{\circ}$ to crossed nicols. (9) Sample 115-709C-25X-5, $60 \mathrm{~cm}$; long axis $45^{\circ}$ to crossed nicols. (10) Sample $115-708 \mathrm{~A}-23 \mathrm{X}-1,130 \mathrm{~cm}$; long axis $45^{\circ}$ to crossed nicols. 11-13. Sphenolithus ciperoensis Bramlette and Wilcoxon. (11) Sample 115-709C-23X-3, $60 \mathrm{~cm}$. (11a) Long axis $45^{\circ}$ to crossed nicols. (11b) Parallel light. (12) Sample 115-710A-16X-4, $130 \mathrm{~cm}$; long axis $45^{\circ}$ to crossed nicols. 


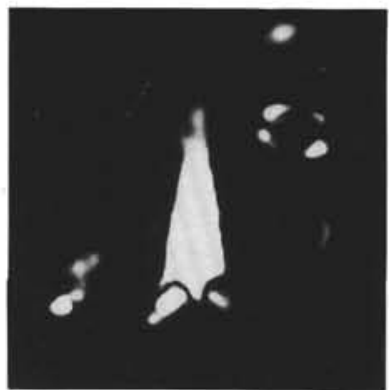

1

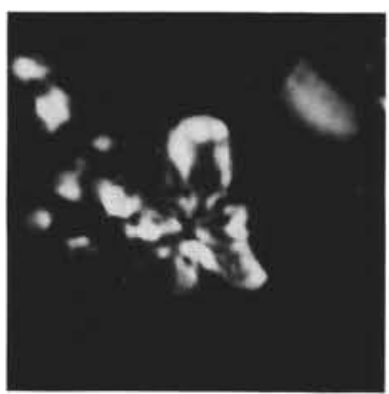

4

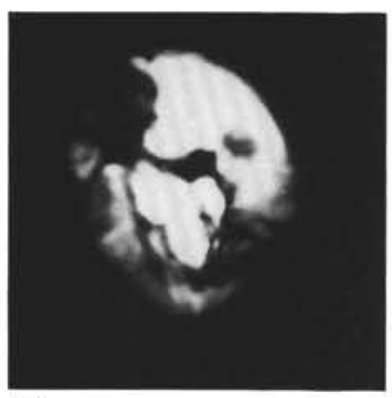

$7 \mathrm{~A}$

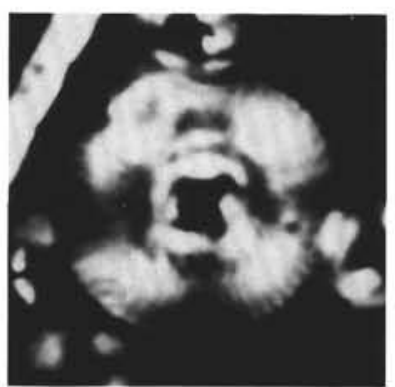

10

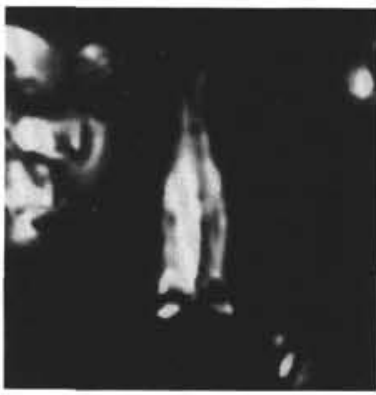

2

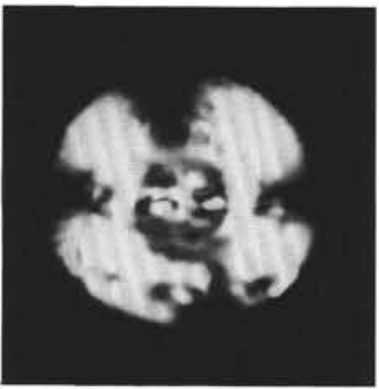

$5 \mathrm{~A}$

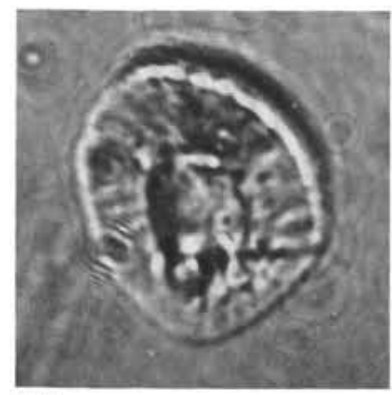

7B

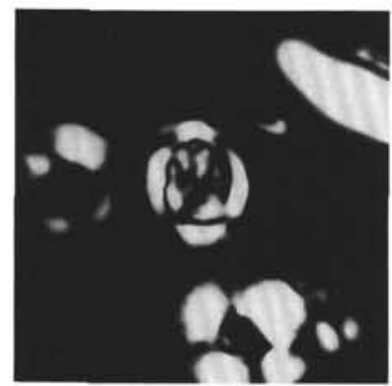

11A

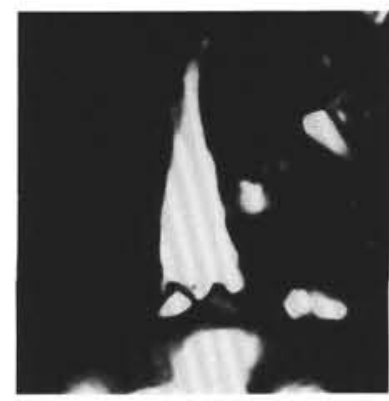

3A

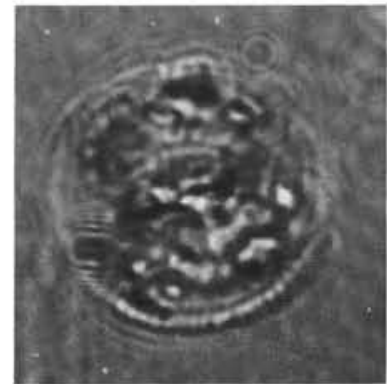

$5 B$

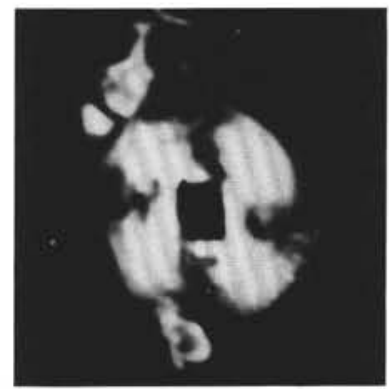

8

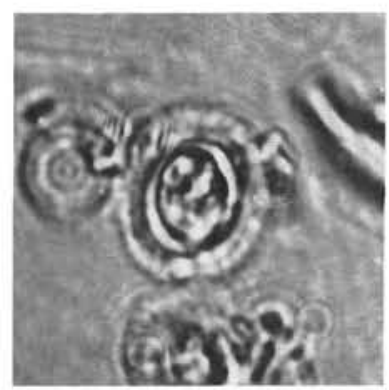

11B

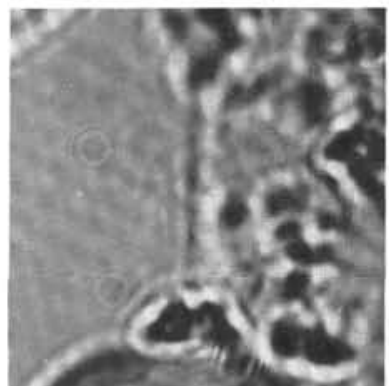

3B

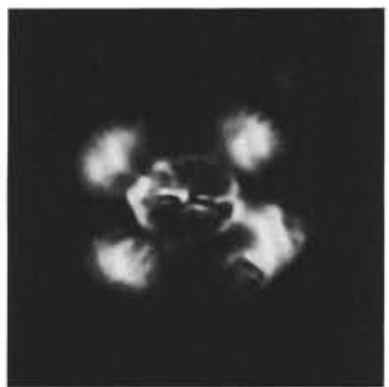

6

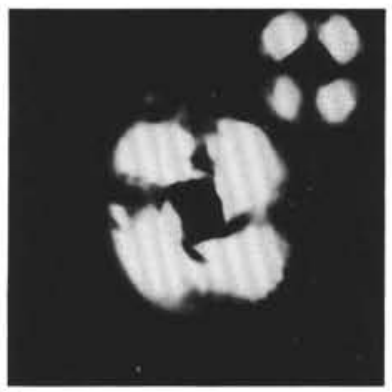

9

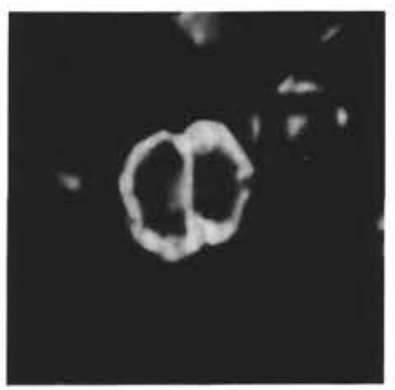

12

Plate 2. All specimens $\times 2400$. 1-3. Sphenolithus sp. 1; Sample 115-711A-16X-1, $130 \mathrm{~cm}$. (1), (2), and (3a) Long axis $45^{\circ}$ to crossed nicols. (3b) Parallel light. 4. Sphenolithus conicus Bukry; Sample 115-709C-22X-4, $60 \mathrm{~cm}$; long axis $45^{\circ}$ to crossed nicols. 5-6. Dictyococcites bisectus (Hay, Mohler and Wade). (5) Sample 115-710A-21X-6, $130 \mathrm{~cm}$. (5a) Crossed nicols. (5b) Parallel light. (6) Sample 115-711A-16X-1, 130 cm; crossed nicols. 7. Helicosphaera compacta Bramlette and Wilcoxon; Sample 115-710A-21X-1, $100 \mathrm{~cm}$. (7a) Crossed nicols. (7b) Parallel light. 8-9. Reticulofenestra sp. 1; Sample 115-710A-21X-5, $100 \mathrm{~cm}$; crossed nicols. 10. Cyclicargolithus abisectus (Müller); Sample 115-710A-16X-4, 130 cm; crossed nicols. 11. Clausicoccus fenestratus (Deflandre and Fert); Sample 115-710A-16X-4, $130 \mathrm{~cm}$. (11a) Crossed nicols. (11b) Parallel light. 12. Zygrhablithus cf. bijugatus; Sample 115-709C-29X-5, $10 \mathrm{~cm}$; crossed nicols. 


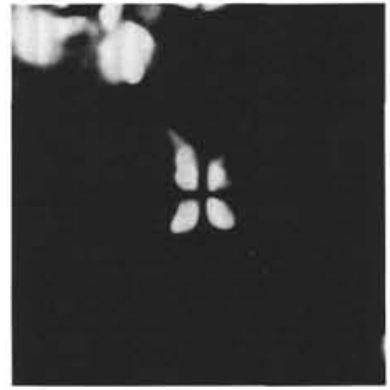

$1 \mathrm{~A}$

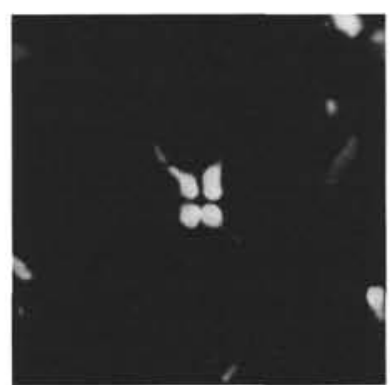

3

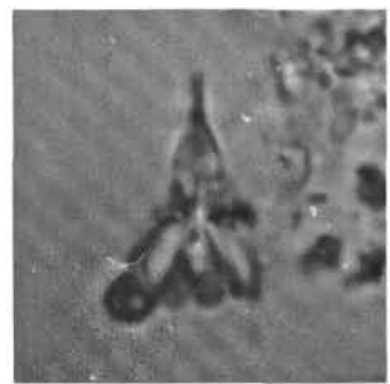

$6 A$

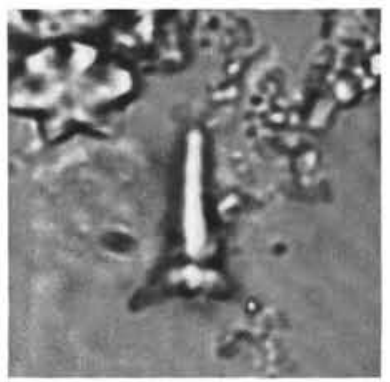

$7 \mathrm{~A}$

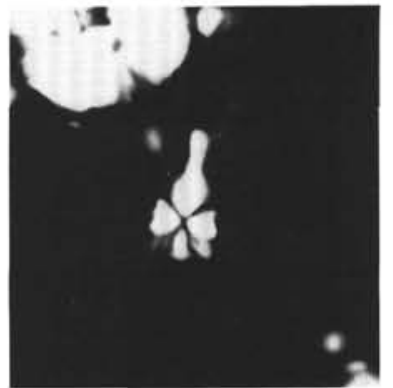

$1 B$

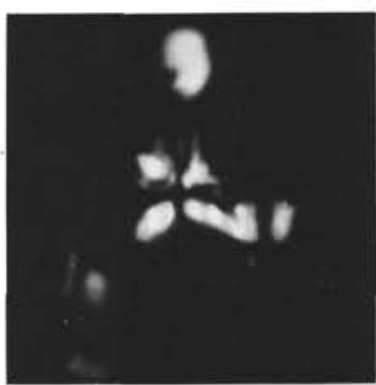

$4 \mathrm{~A}$

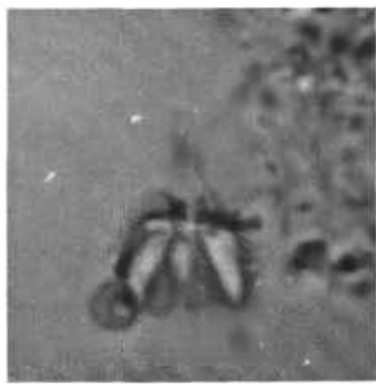

6B

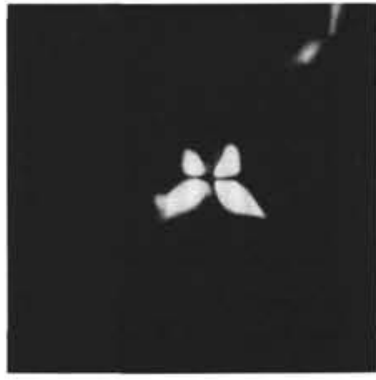

$7 B$

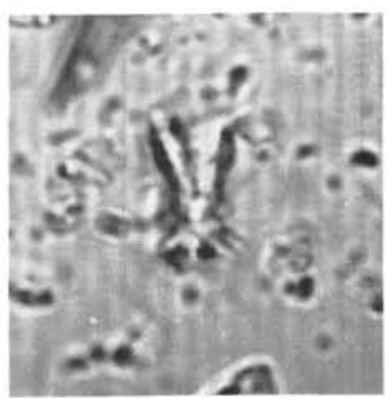

$2 \mathrm{~A}$

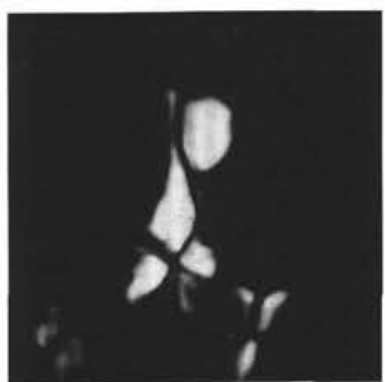

4B

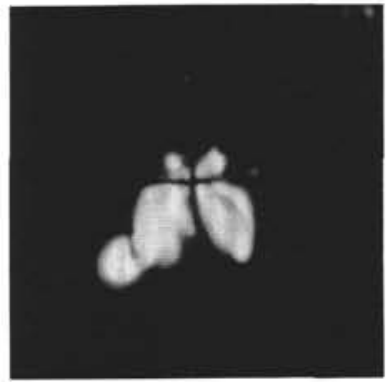

$6 C$

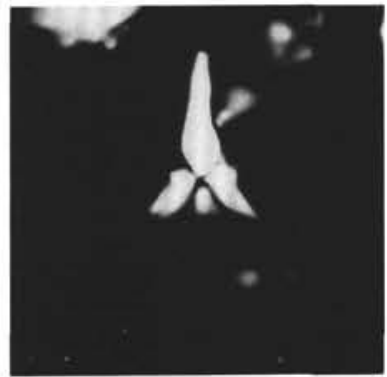

$7 \mathrm{C}$

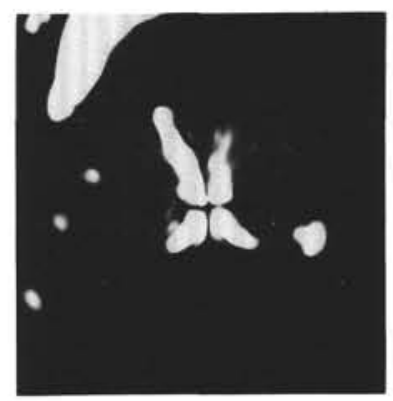

2B

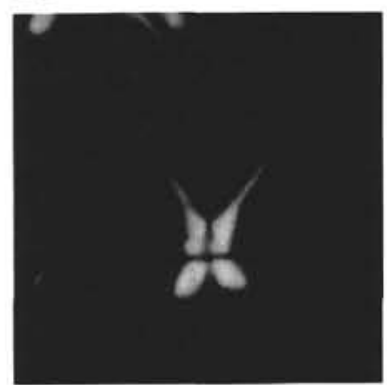

5

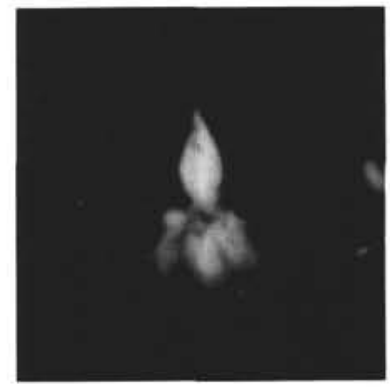

6D

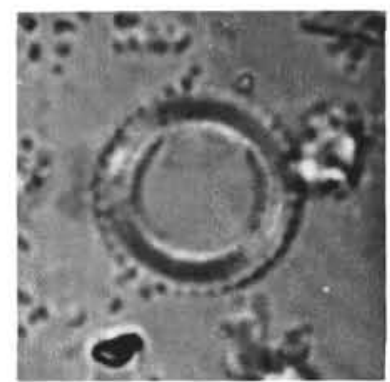

8

Plate 3. All specimens $\times 2400$. 1-3. Sphenolithus multispinatus Fornaciari and Rio; Sample $115-715 \mathrm{~A}-10 \mathrm{R}-3,130 \mathrm{~cm}$. (1a), (2b), and (3) Long axis $0^{\circ}$ to crossed nicols. (1b) Long axis $45^{\circ}$ to crossed nicols. (2a) Parallel light. 4. Sphenolithus pseudoheteromorphus Fornaciari and Rio; Sample $115-714 \mathrm{~A}-19 \mathrm{X}-1,130 \mathrm{~cm}$. (4a) Long axis $0^{\circ}$ to crossed nicols. (4b) Long axis $45^{\circ}$ to crossed nicols. 5. Sphenolithus capricornutus Bukry and Percival; Sample 115-714A-21X-CC; long axis $0^{\circ}$ to crossed nicols. 6. Sphenolithus milanetti Fornaciari and Rio; Sample 115-714A-16X-3, 130 cm. (6a) Parallel light; long axis $0^{\circ}$. (6b) Parallel light; long axis $90^{\circ}$. (6c) Long axis $90^{\circ}$ to crossed nicols. (6d) Long axis $45^{\circ}$ to crossed nicols. 7. Sphenolithus delphix Bukry; Sample 115-714A-21X-CC. (7a) Parallel light. (7b) Long axis $0^{\circ}$ to crossed nicols. (7c) Long axis $45^{\circ}$ to crossed nicols. 8 . Coronocyclus nitescens (Kamptner); Sample 115-714A-10H-4, $75 \mathrm{~cm}$; parallel light. 